$S$

HNF-1886

Revision 1

\title{
Central Waste Complex Waste Analysis Plan
}

Prepared for the U S Department of Energy

Assistant Secretary for Environmental Management

Project Hanford Management Contractor for the

US Department of Energy under Contract DE AC06-96RL13200

Fwor bawn whrond, inc.

PO Box 1000

Richland Washington 


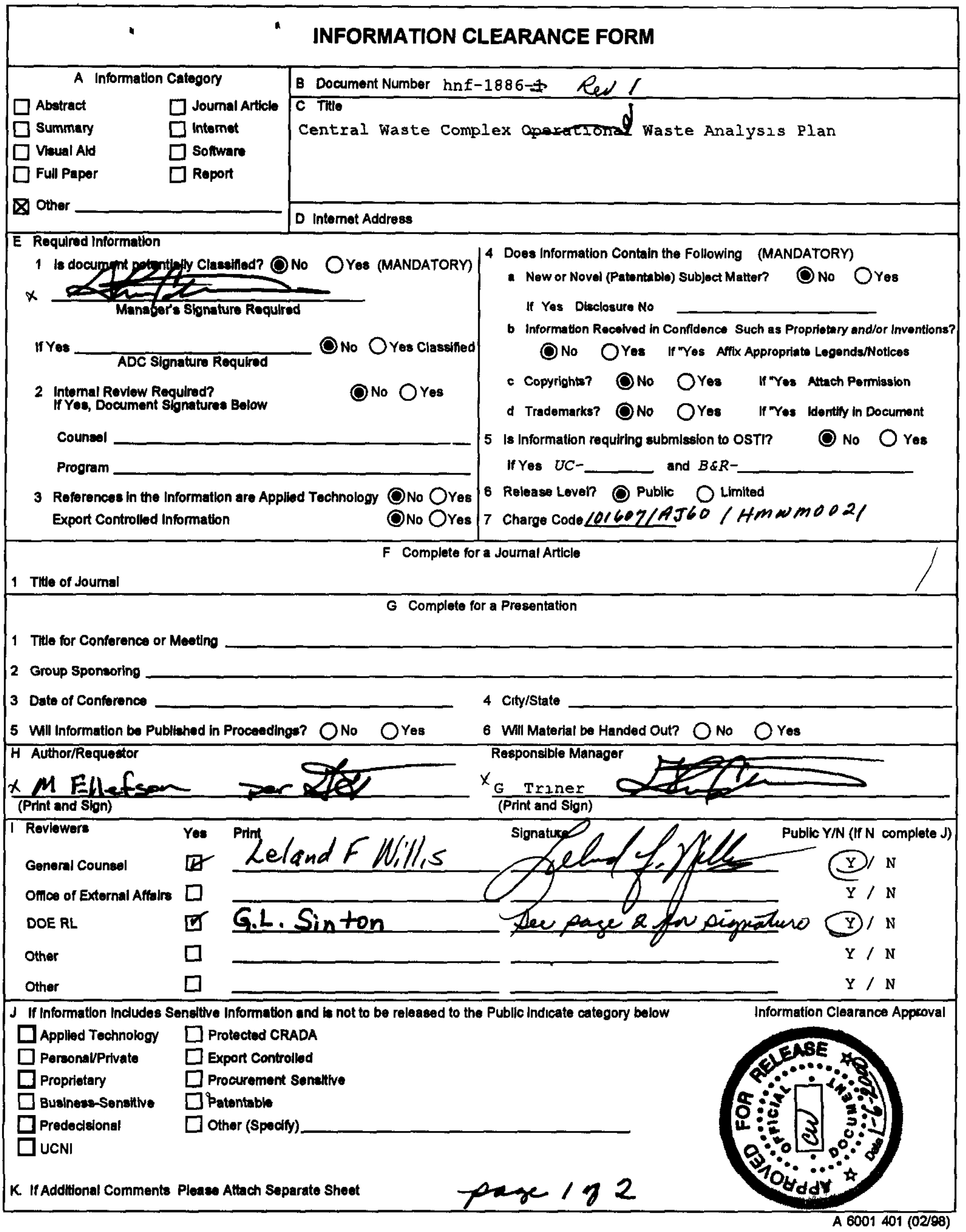




\section{INFORMATION CLEARANCE FORM}

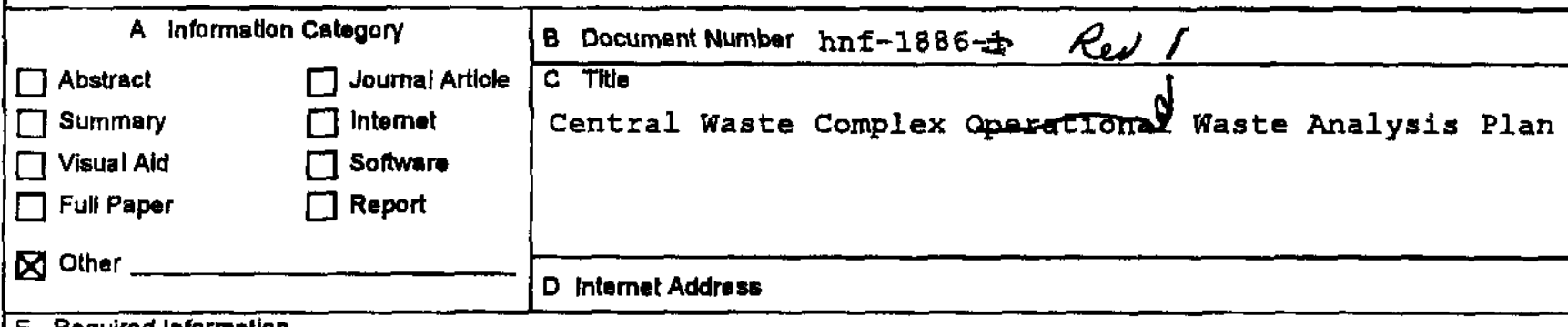

E Required Information

If Yes $\frac{\text { Is docump }}{\text { ADC signature Required }}$ ONo OYes Claseined

2 Internal Reviow Required?

If Yes Document Slgnatures Below

ONo OYas

Counsel

Program

3 References in the information are Applied Technology ONo OYes Export Controlled Information
4 Does information Contain the Following (MANDATORY)

- Now or Noval (Patentablo) subject Matton O No OYes

If Yos Dlaclosure No

b Information Recalved In Confidence Such as Proprietary and/or Inventions? ONo OYes if "Yos Amix Appropriate Legends/Noticess

c copyrights? ONo OYes "Yes" Autach Permussion

d Trademarks? ONo OYes If Yos kdently In Document

5 is Information requining submission to OSTI? $O$ No $O$ Yes

IfYes UC-_ and BCR-

6 Release Level? $\bigcirc$ Public $O$ Limited

7 charge Code $10160714560 / 4 m w m 0021$

F Complete for a Joumal Article

1 Title of Journal

G Complete for a Presentation

1 Tille for Conference or Metung

2 Group Sponeoring

3 Date of Conference

4 Clty/State

5 Will Information be Published in Proceedings? ONo OYes

H Author/Requestor

X M Elteforan (Print and Sign)

1 Roviewers

General Couneel

Yes Print

Orfice of External Aftalis

DOE RL

IF Leland $F M / 1 /$ is

6 Will Material be Handed Out? Responalble Manager

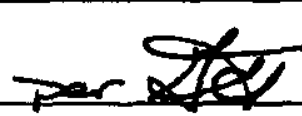
$X_{G \text { Triner }}$ (Print and Slon)

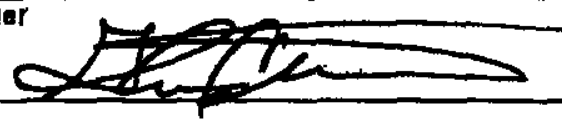

signatury $r$

Other

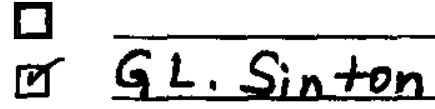

Other

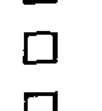

0
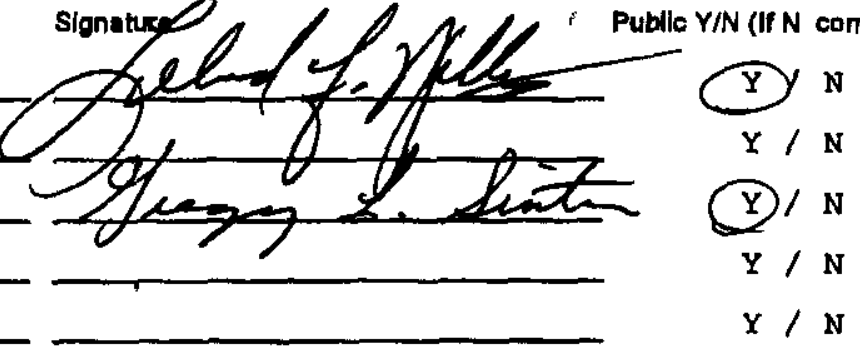

I If Information Includes Senditive information and ta not to be relenced to the Publlo indicate calegory below
$\square$ Applied Technology
$\square$ Protected CRADA
$\square$ Personal/Pnvate
$\square$ Export Controlled
$\square$ Proprielary
$\square$ Procurement-Seneltive
$\square$ Business Sensitive
$\square$ Patentable
$\square$ Predecisional
$\square$ other (specily).
$\square$ UCNi

K If Additional Comments Ploase Altach Separate sheet

$$
\text { Page } 2 z^{2}
$$


HNF-1886

Revision 1

\section{Central Waste Complex Waste Analysis Plan}

M Ellefson

Fluor Hanford, Inc

Date Published

December 1999

Prepared for the U S Department of Energy

Assistant Secretary for Environmental Management

Fwon Davant murond, inc.

PO Box 1000

Richland Washington 
TRADEMARK DISCLAIMER

Reference herein to any specific commercial product process

or service by trade name trademark manufacturer or

otherwise does not necessarly constitute or imply its

endorsement recommendation or favoring by the United

States Government or any agency thereof or its contractors or subcontractors

This report has been reproduced from the best avallable copy

Printed in the United States of America 


\section{RELEASE AUTHORIZATION}

Document
Number

Document

Title

Central Waste Complex Waste Analysis Plan

\section{This document, reviewed in accordance with \\ DOE Order 241 1, "Scientific and Technical \\ Information Management," and DOE G 241 1-1, \\ "Guide to the Management of Scientific and \\ Technical Information," does not contain \\ classified or sensitive unclassified information \\ and is}

\section{APPROVED FOR PUBLIC RELEASE}

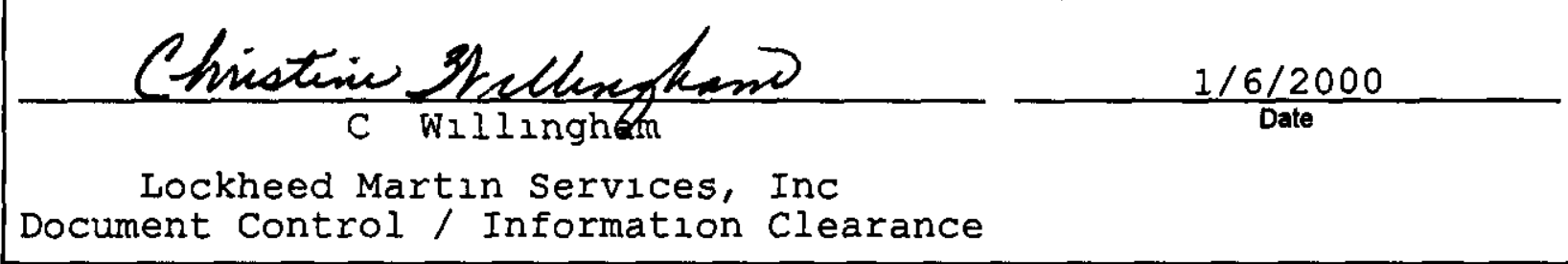

Revlewed for Applied Technology Business Sensitive Classified Copyrighted Export Controlled Patent Personal/Private Proprletary Protected CRADA Trademark Unclassified Controlied Nuclear Information

TRADEMARK DISCLAIMER Reference herein to any specific commercial product process or service by trade name, trademark manufacturer or otherwise does not necessarily constitute or imply its endorsement recommendation or favoring by the United States Government or any agency thereof or its contractors or subcontractors The vlews and opinions of authors expressed herein do not necessarily stale or reflect those of the United States Government or any agency thereof This report has been reproduced from the best available copy

Printed in the United States of America

Available to the U S Department of Energy and its contractors from the U S Department of Energy Office of Scientific and Technical information PO Box 62 Oak Ridge TN 37831 Telephone 423/576-8401

Available to the public from the U S Department of Commerce National Technical Information Service 5285 Port Royal Road Springfield VA 22161 Telephone $703 / 487-4650$ 
HNF 1886-1

\section{CONTENTS}

10 UNIT DESCRIPTION 11

METRIC CONVERSION CHART

11 DESCRIPTION OF UNIT PROCESSES AND ACTIVITIES 11

111 How Waste is Accepted, Moved Processed, and Managed 1-1

1111 Narrative Process Descriptions $\quad 11$

1112 Waste Acceptance Process 11

1113 Description of Performance Evaluation System 13

112 Process Flow Diagram 15

113 Operatıng Conditions $1-5$

12 IDENTIFICATION AND CLASSIFICATION OF WASTE

20 CONFIRMATION PROCESS 2-1

21 PRE SHIPMENT REVIEW 21

211 Waste Stream Approval Process 21

212 Waste Shipment Approval Process $\quad 22$

213 Acceptable Knowledge Requirements 2-3

2131 General Acceptable Knowledge Requirements 2-3

2132 Methodology to Ensure Compliance with Land Disposal Restrictions Requirements

22 VERIFICATION 25

221 Container Receipt Inspection 25

222 Physical Screening Process 25

2221 Physical Screening Methods $2-6$

2222 Physical Screening Frequency $\quad 2-6$

2223 Physical Screening Exceptions $2-6$

223 Chemical Screening Process $2-7$

2231 Chemical Screening Frequency 2-8

2232 Chemical Screening Exceptions 2-8

224 Sampling for Confirmation Screening 2-8

225 Quality Assurance and Quality Control for Confirmation Process 2-9

2251 Physical Screening Quality Control 2-9

2552 Chemical Screenıng Quality Control 2-9

SELECTING WASTE ANALYSIS PARAMETERS 31

PHYSICAL SCREENING PARAMETERS 31

CHEMICAL SCREENING PARAMETERS $\quad 32$

OTHER ANALYSIS PARAMETERS

SELECTING SAMPLING PROCEDURES 4-1

SAMPLING STRATEGIES $\quad 41$

SAMPLING METHODS 4-1

SELECTING SAMPLING EQUIPMENT $\quad 42$

SAMPLE PRESERVATION

ESTABLISHING QUALITY ASSURANCE AND QUALITY CONTROL PROCEDURES

FOR SAMPLING $\quad$ 4-2 
HNF 1886-1

4

5

8

10

1170

1271

$13 \quad 72$

$14 \quad 73$

$15 \quad 74$

16

17

\section{CONTENTS (cont)}

50 SELECTING A LABORATORY, LABORATORY TESTING, AND ANALYTICAL METHODS

SAMPLING PROGRAM RESTRICTION REQUIREMENTS

743 Land Disposal Restriction Certification of Treatment

$$
80 \text { RECORDKEEPING }
$$

90 REFERENCES

APP A-1

A ANALYTICAL PARAMETERS, METHODS, AND RATIONALE FOR WASTE RECEIVED AT THE CENTRAL WASTE COMPLEX

\section{FIGURES}

Figure 11 Central Waste Complex Site Plan $\quad$ 1-1

Figure 12 Flammable and Alkalı Metal Waste Storage Buılding $\quad 1-2$

$\begin{array}{lll}\text { Figure } 13 & 2401-W \\ & \text { Waste Storage Buldıng } & 1-3\end{array}$

Figure 142402 W Waste Storage Building $\quad 1-4$

Figure 152403 WA through WC Waste Storage Building $1-5$

Figure 16 2403-WD Waste Storage Building $\quad$ 1-6

Figure 1-7 2404-W Waste Storage Buildings $\quad 1-7$

Figure 18 Waste Storage Pad $\quad 1-8$

Figure 19 Central Waste Complex Waste Analysis Plan Flowchart $\quad$ 1-8

Figure 21 Waste Acceptance Process $2-1$

TABLE

41 Central Waste Complex Chemical Screening Sampling Equipment

T4-1 


\section{GLOSSARY}
ALARA
as low as reasonably achievable
ASTM
American Society for Testıng and Materials
AWMP
alternative waste management plan
corrective action plan
COLIWASA
composite liquid waste sampler
CFR
CWC
Code of Federal Regulations
Central Waste Complex

\section{DOE RL}
DQO
Ecology
HNF
LDR
LLBG
MSDS
NDA
NDE
PCB
PES
$\mathrm{pH}$
QA/QC
RCRA
RCW
SWITS
SWMU
TRU
WAC
WAP
WSRd
U S Department of Energy, Richland Operations Office
data quality objectıves
Washington State Department of Ecology
Hanford Nuclear Facılity (document identıfier)
land disposal restriction
Low-Level Burial Grounds
material safety data sheet
nondestructive assay
nondestructive examination
polychlorinated biphenyl
performance evaluation system
negative logarithm of the hydrogen ion concentration
quality assurance and quality control
Resource Conservation and Recovery Act of 1976
Revised Code of Washington
solid waste information tracking system
solid waste management unit
transuranic
Washıngton Admınıstratıve Code
waste analysis plan
waste specification record
degrees Celsius

6 CAP

43

$44 \quad{ }^{\circ} \mathrm{C}$ 


\section{METRIC CONVERSION CHART}

The following conversion chart is provided to the reader as a tool to aid in conversion

Into metric units

Out of metric units

\begin{tabular}{|c|c|c|c|c|c|}
\hline If you know & Multıply by & To get & If you know & Multıply by & To get \\
\hline \multicolumn{3}{|c|}{ Length } & \multicolumn{3}{|c|}{ Length } \\
\hline inches & 2540 & millimeters & millımeters & 00393 & inches \\
\hline inches & 254 & centımeters & centımeters & 0393 & inches \\
\hline feet & 03048 & meters & meters & 32808 & feet \\
\hline yards & 0914 & meters & meters & 109 & yards \\
\hline miles & 1609 & kılometers & kılometers & 062 & miles \\
\hline \multicolumn{3}{|c|}{ Area } & \multicolumn{3}{|c|}{ Area } \\
\hline square inches & 64516 & $\begin{array}{l}\text { square } \\
\text { centımeters }\end{array}$ & $\begin{array}{l}\text { square } \\
\text { centımeters }\end{array}$ & 0155 & square inches \\
\hline square feet & 0092 & square meters & square meters & 107639 & square feet \\
\hline square yards & 0836 & square meters & square meters & 120 & square yards \\
\hline square miles & 259 & $\begin{array}{l}\text { square } \\
\text { kilometers }\end{array}$ & $\begin{array}{l}\text { square } \\
\text { kilometers }\end{array}$ & 039 & square miles \\
\hline acres & 0404 & hectares & hectares & 2471 & acres \\
\hline \multicolumn{3}{|c|}{ Mass (weight) } & \multicolumn{3}{|c|}{ Mass (weight) } \\
\hline ounces & 2835 & grams & grams & 00352 & ounces \\
\hline pounds & 0453 & kılograms & kılograms & 22046 & pounds \\
\hline short ton & 0907 & metric ton & metric ton & 110 & short ton \\
\hline \multicolumn{3}{|c|}{ Volume } & \multicolumn{3}{|c|}{ Volume } \\
\hline fluid ounces & 2957 & milliliters & milliliters & 003 & fluid ounces \\
\hline quarts & 095 & liters & liters & 1057 & quarts \\
\hline gallons & 379 & liters & liters & 026 & gallons \\
\hline cubic feet & 003 & cubic meters & cubic meters & 353147 & cubic feet \\
\hline cubic yards & 076 & cubic meters & cubic meters & 1308 & cubic yards \\
\hline \multicolumn{3}{|c|}{ Temperature } & \multicolumn{3}{|c|}{ Temperature } \\
\hline Fahrenheit & $\begin{array}{l}\text { subtract } 32 \\
\text { then } \\
\text { multıply by } \\
5 / 9 \text { ths }\end{array}$ & Celsius & Celsıus & $\begin{array}{l}\text { multiply by } \\
9 / 5 \text { ths, then } \\
\text { add } 32\end{array}$ & Fahrenheit \\
\hline
\end{tabular}

Source Engineering Unit Conversions, M R Lindeburg PE, Second Ed, 1990, Professional Publications, Inc, Belmont, Calıfornia 
HNF-1886-1

The purpose of this waste analysis plan (WAP) is to document the waste acceptance process, sampling methodologies, analytıcal technıques, and overall processes that are undertaken for waste accepted for storage at the Central Waste Complex (CWC), which is located in the 200 West Area of the Hanford Facility, Richland, Washington Because dangerous waste does not include the source special nuclear and by-product material components of mixed waste, radionuclides are not within the scope of this documentation The information on radionuclides is provided only for general knowledge

This document has been revised to meet the interim status waste analysis plan requirements of Washington Administrative Code (WAC) 173 303-300(5) When the final status permit is issued, permit conditions will be incorporated and this document will be revised accordingly

\section{DESCRIPTION OF UNIT PROCESSES AND ACTIVITIES}

The CWC is a nonland-based unit consistıng of varıous buldings, storage modules, and storage pad (Figure 1 1) The CWC structures are used for the storage of waste and are subject to Dangerous Waste Regulations WAC 173-303 and 40 Code of Federal Regulations (CFR) 761

The CWC consists of the $2401 \mathrm{~W}, 2402-\mathrm{W}, 2403-\mathrm{W}$ and $2404-\mathrm{W}$ waste storage buildings, Flammable and Alkalı Metal Waste Storage Modules, the waste storage pad, and the waste receiving and staging area (Figures 1-2 through 18 ) Further discussion on these structures can be found in Chapter 20 of the Hanford Facility Dangerous Waste Permit Application Central Waste Complex (DOE/RL-91-17)

\section{How Waste is Accepted, Moved, Processed, and Managed}

The following sections and the flowchart on page F2 1 describe the different types of information and knowledge used for waste acceptance

\section{Narrative Process Descriptions}

The onsite generating unit, offsite generator and treatment, storage, and/or disposal (TSD) unit transferring waste to the CWC is hereafter referred to as a 'generator' unless otherwise denoted in this WAP

Waste that meets land disposal restriction (LDR) requirements, as specified in 40 CFR 268 and WAC 173-303-140, is stored in the CWC Waste not meeting LDR requirements, but awaitıng further treatment offsite or onsite either at the Waste Receiving and Processing Facility (WRAP) or the T Plant Complex (T Plant) can be stored at the CWC Unless excepted or otherwise discussed in Section 21 of this WAP, the CWC unit-specific operating record will contain information necessary to meet LDR requirements for any waste awaiting further treatment Containerized waste that is not fully characterized or is awaiting sampling results can be stored in CWC The Hanford Facility is required to sample certain waste depending on the type of treatment standard to ensure that the waste or treatment residuals are in compliance with applicable LDR requirements Such testing is performed according to the frequency specified in this WAP

\section{Waste Acceptance Process}


- Waste Stream Approval The generator provides information concerning each waste stream on a waste profile sheet The waste stream information is reviewed against the CWC waste acceptance criteria However, waste that previously was accepted at a Waste Management Project operated TSD unit does not require the development or redevelopment of a waste profile and is exempt from the waste stream approval function If the waste stream information is sufficient and meets the applicable acceptance criteria, the waste stream is approved ${ }^{\prime}$ In addition the initial verification frequency for the waste is determined in accordance with the requirements found in the performance evaluation program (PES) (Section 11113 ) For a more complete description of the waste stream approval process refer to Section 211

- Waste Shipment Approval The generator provides specific data for each waste container The container data are reviewed against the waste profile sheet data and the CWC acceptance criteria before being approved for shipment In addition the CWC operating organization or its representative, hereafter referred to the 'CWC operating organization', determines if any of the containers require verification based on the verification frequency as determıned by PES For a more complete description of the waste transfer/shipment approval process refer to Section 212

- Verification Verification activities include container receipt inspection and also could include physical screening and/or chemical screening All containers received at the CWC are receipt inspected before acceptance, and a percentage of waste containers are selected for physical and/or chemical screening during the waste shipment approval process These containers can be inspected visually verified by nondestructive examination (NDE) or sampled for field or laboratory analysis to confirm that the waste matches the waste profile and container data information supplied by the generator Any discrepancies between the verification results and the waste profile sheet must be resolved before final acceptance at CWC in accordance with the conformance issue resolution process found in Section 11133

\section{Types of Acceptable Knowledge}

30 | When collecting documentation on a waste stream or container, the CWC operating organization must determine if the information provided by the generator is acceptable knowledge Acceptable knowledge requirements are met using any one or a combination of the following types of data

- Mass balance from a controlled process that has a specified input for a specified output

- Material safety data sheets (MSDSs) on unused chemical products

- Test data from a surrogate sample

- Analytical data on the waste or a waste from a simılar process

In addition, acceptable knowledge requirements can be met using a combination of analytical data or screening results and one or more of the following

- Interview information

- Logbooks

- Procurement records

- Qualıfied analytical data

- Radiation work package

1 Approved waste profiles will be retained in the Operatıng Record and will be made available to regulators upon request 
- Procedures and/or methods

- Process flow charts

- Inventory sheets

- Vendor information

- Mass balance from an uncontrolled process (e $g$, spill cleanup)

- Mass balance from a process with variable inputs and outputs ( $\mathrm{g}$, washıng/cleaning methods)

If the information is sufficient to quantify constituents of regulatory concern and determine waste characteristics as required by the regulations and CWC acceptance criteria, the information is considered acceptable knowledge The CWC acceptance criteria is defined as the requirements found in this WAP and the associated Part A, Form 3 (DOE/RL-88 21)

\section{Description of Performance Evaluation System}

The PES determines the inttial physical screening frequency of each generator waste stream PES provides a periodic status of an individual generator's performance for waste received Also, PES provides a mechanısm for determıning corrective actions, resolving waste acceptance issues, and physical screening frequency adjustments when a problem has been discovered

\section{Inıtıal Physıcal Screenıng Frequency Determinatıon}

The initial physical screenıng frequency is determined based on the following process

- CWC operating organızation reviews the generator waste profile information to determıne the relative potential for misdesignation or inappropriate segregation based on all relevant information, including any previous experience with the generator Based on this review, CWC operating organization identifies any concerns associated with the following criteria

- documented waste management program

- waste stream characterization information

- potential for inappropriate segregation

- Based on the identıfication of concerns during the review, the CWC operating organization establishes the initial physical screening frequency for the new generator's waste stream based on the following criteria

- Inıtıal physıcal screenıng frequency of, at a mınımum 20 percent No concerns identıfied

- Initial physical screenıng frequency of, at a mınımum, 50 percent Concern(s) identıfied in one criterion

- Initıal physical screening frequency of 100 percent Concerns identıfied in two or more criterıa

A performance evaluation is used to trend a generator's performance and is used to raise the generator $s$ overall group of streams physical screening frequency based on the type of issue The evaluation should be objective and should consider the conformance issues documented during the preshipment review and 
1 deficiencies and conformance issues identified, (2) evaluate unsatisfactory performance for corrective actions and (3) adjust physical screening rates accordingly

\section{Conformance Issue Resolution}

5 Conformance issues identified during verification could result in a waste container that does not meet CWC waste acceptance criteria If a possible conformance issue is identified, the following actions are taken to resolve the issue

- CWC operating organization comples all information concerning the possible conformance issue(s)

- The generator is notified and requested to supply additional knowledge to assist in the resolution of the concern(s) If the generator supplies information that alleviates the concern(s) identified, no further action is required

- Upon determination that a conformance issue has been identıfied, the CWC operatıng organization personnel and the generator discuss the conformance issue and identify the appropriate course of action to resolve the container/shipment in question, 1 e, pick another sample set, return the container/shipment, divert the container/shipment to another TSD unit that can accept the container/shipment and resolve the issue, or the generator resolves the issue at the TSD unit If the conformance issue(s) results in the failure of a shipment, the physical screening frequency for all | streams that could exhibit a similar issue(s) from the generator are adjusted to 100 percent untıl the issue(s) adequately can be addressed

- On resolution of the initial conformance issue, CWC operating organization requests the generator to provide a corrective action plan (CAP) that clearly states the reason for the fallure and describes the actions to be completed to prevent re-occurrence The generator could request a reduction in verification of additional streams the generator believes are unaffected This request must be accompanied by a justification that identifies why this stream(s) would not exhibit the same conformance issue

- CWC operating organization reviews the CAP and stream justification for adequacy If the stream justification is adequate, CWC operatıng organization could provide an alternative frequency as denoted in Section 111132

\section{Process for Reducing the Physical Screening Frequency}

Screening rate frequencies and changes to those frequencies could be applied to a specific waste stream, to a specific contractor or to a specific offsite generator based on the circumstances surrounding the conformance issue After the initial screening frequency for a given waste stream has been established or increased, the physical screening frequency can be reduced in accordance with the following process

The physical screening frequency will be reduced in three steps Reduction for all steps is based on the

ability to demonstrate that five containers from the waste stream in question pass verification In

42 addition, reduction to the mınımum frequency requires that the CWC operating organization documents

43 | an acceptable evaluation of the CAP At no time will the physical screening frequency be reduced below 445 percent for waste generated onsite or below 10 percent for offsite generators

45 | Step 1 Reduce frequency by a maxımum of 66 percent after five containers from the waste stream 46 in question pass verification

47 - Step 2 Reduce frequency established in Step 1 by a maxımum of 50 percent or to the minımum 
allowable, whichever results in a greater frequency after five containers from the waste stream in question pass verification

- Step 3 Reduce frequency to the minimum allowable after five containers from the waste stream in question pass verification The CWC operating organization documents an acceptable evaluation of the corrective action plan

\section{Process Flow Diagram}

Refer to Figure 2-1 for the waste analysis plan flowchart and Section 11 for description

\section{Operatıng Conditions}

The following conditions and constraints apply to waste accepted at CWC The waste container weight must be known and proper handing procedures imposed to ensure safe operations The waste container radiation dose must be known and procedures must ensure that personnel exposure is kept as low as is reasonably achievable (ALARA) The quantity of fissile material within the waste must be determined and must be low enough to prevent a criticality hazard Liquid waste is allowed when packaged in compatible inner containers, surrounded with a sufficient quantity of sorbent to sorb the total liquid quantity of the waste package Residual liquid is allowed when sorbent is placed in the bottom of the outer container or is dispersed among the waste in sufficient quantity to sorb the total residual liquid content of the waste package Containers of waste that cause pressurization must be vented Radionuclide and dangerous waste constituent inventories in waste containers must be kept low enough to ensure that personnel emergency exposure limits are not exceeded

The Part A, Form 3, permit application for CWC identifies dangerous waste numbers, quantities, and design capacity (DOE/RL-88 21)

Dangerous and/or mixed waste with waste numbers not identified on the CWC Part A Form 3, will not be managed at CWC Additionally, waste for which $\mathrm{CWC}$ is unable to obtain the information required by WAC 173303300 will not be managed in CWC

\section{IDENTIFICATION AND CLASSIFICATION OF WASTE}

34 Waste is accepted for treatment (mixed waste) and/or storage (mixed and dangerous) in CWC except for 35 the following waste types

- Bulk liquid waste

- Explosive waste

- Shock sensitive waste

- Class IV oxidizer waste

- Infectious waste 
CWC manages the following waste types

- Labpack liquids

- Solids/debris

- Sludges/soils

6

7 These waste types could be classified as transuranic, low-level mixed, and/or dangerous Unless

8 otherwise prohibited by this WAP, the waste could exhibit the characteristics of ignitable, toxic,

9 corrosive, and/or reactive In addition to the waste received at CWC for verification or reprocessing,

10 CWC generates mixed and dangerous waste This waste material consists of items such as personal 11 protective equipment (PPE), rags, and spent equipment contaminated with dangerous cleaning agents, 12 lubricants, paints, or other dangerous materials Process knowledge, field screenıng, or sampling and 13 analysis are used as appropriate to characterize these waste materials Field screening and sampling are 14 in accordance with this WAP and occur at the point of waste generation or at the location where the 15 waste materials are stored 


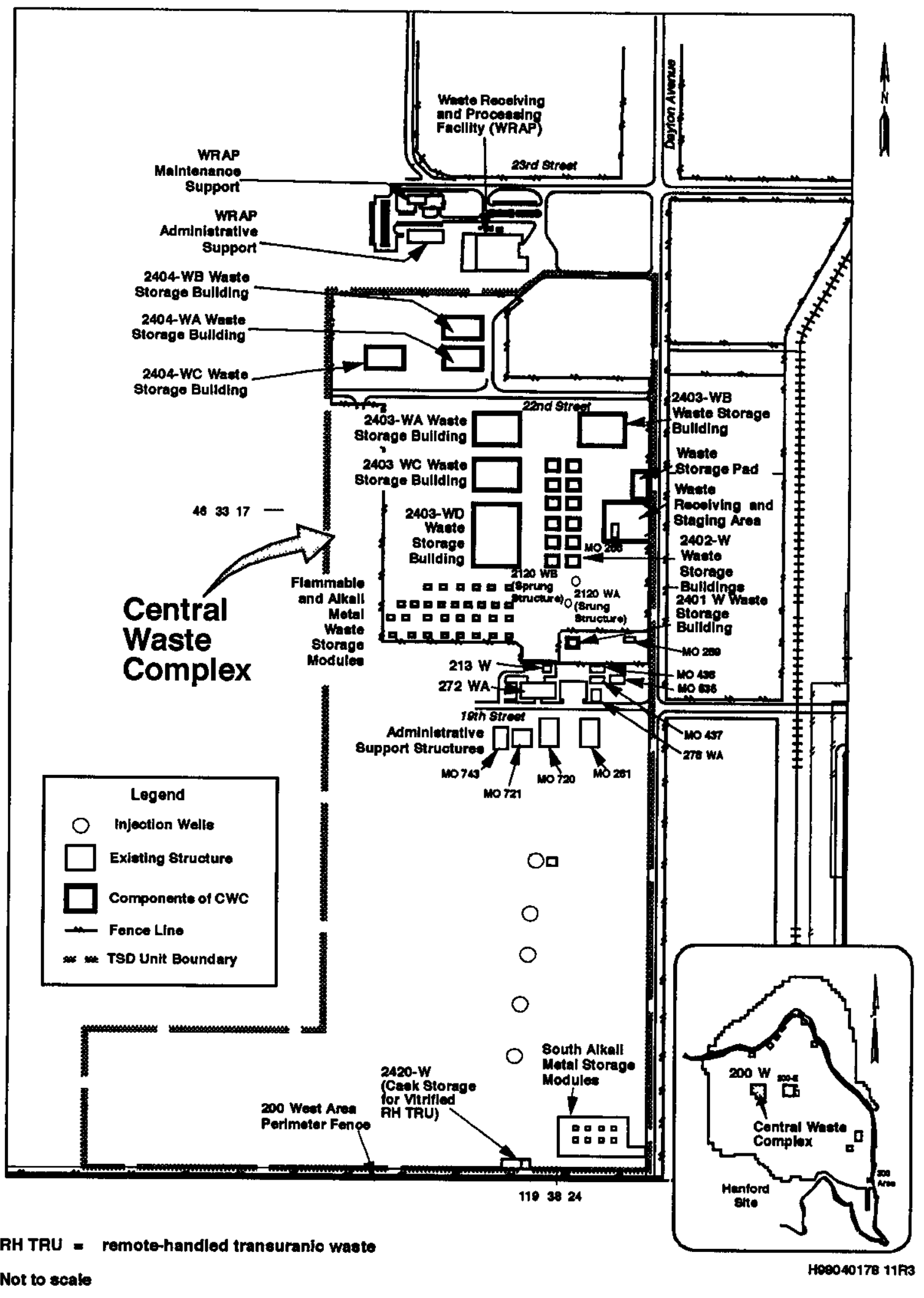

Refer to topographic map (H 13-000003) for detall

Figure 1-1 Central Waste Complex Site Plan 


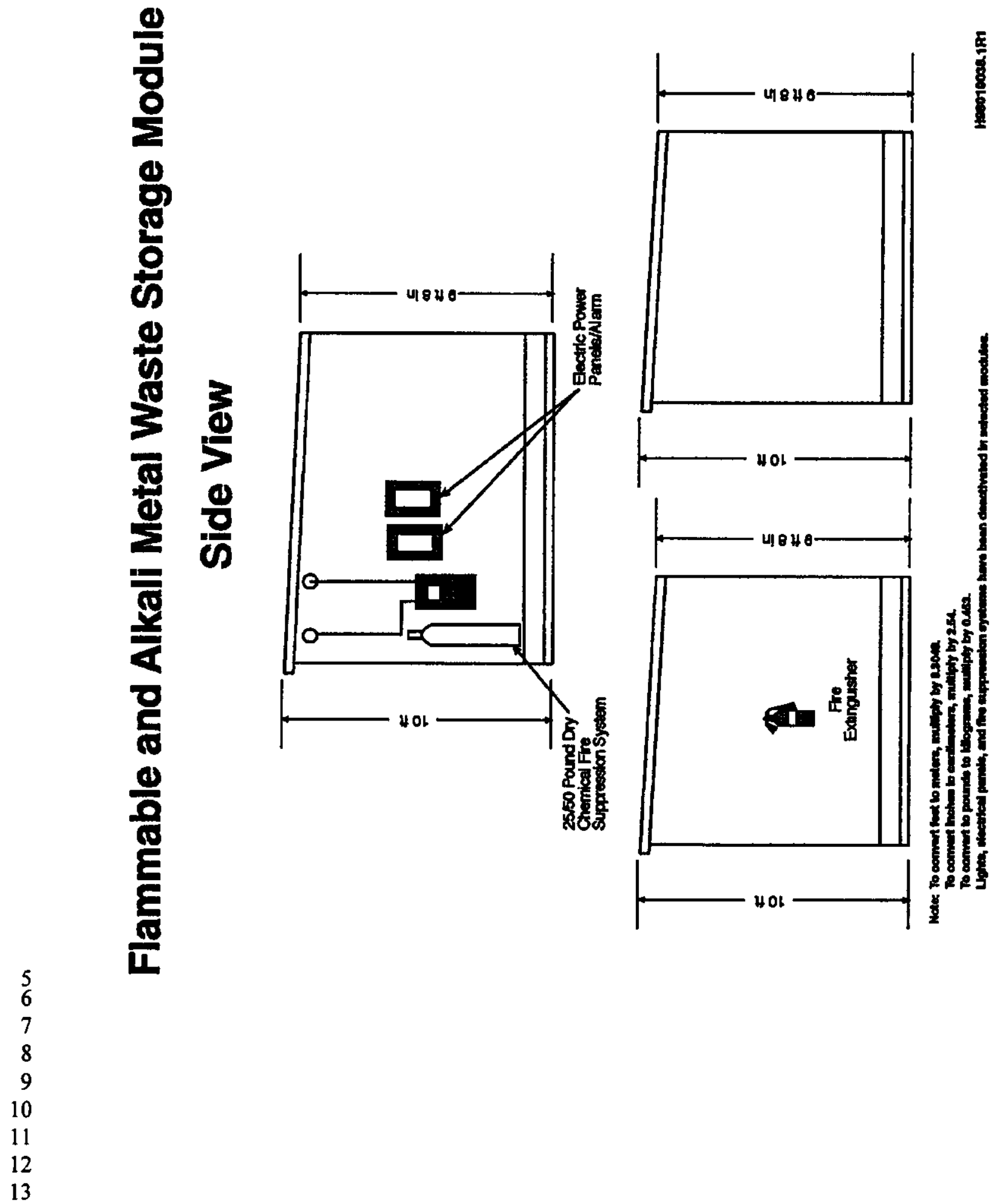

Figure 1-2 Flammable and Alkalı Metal Waste Storage Buılding 

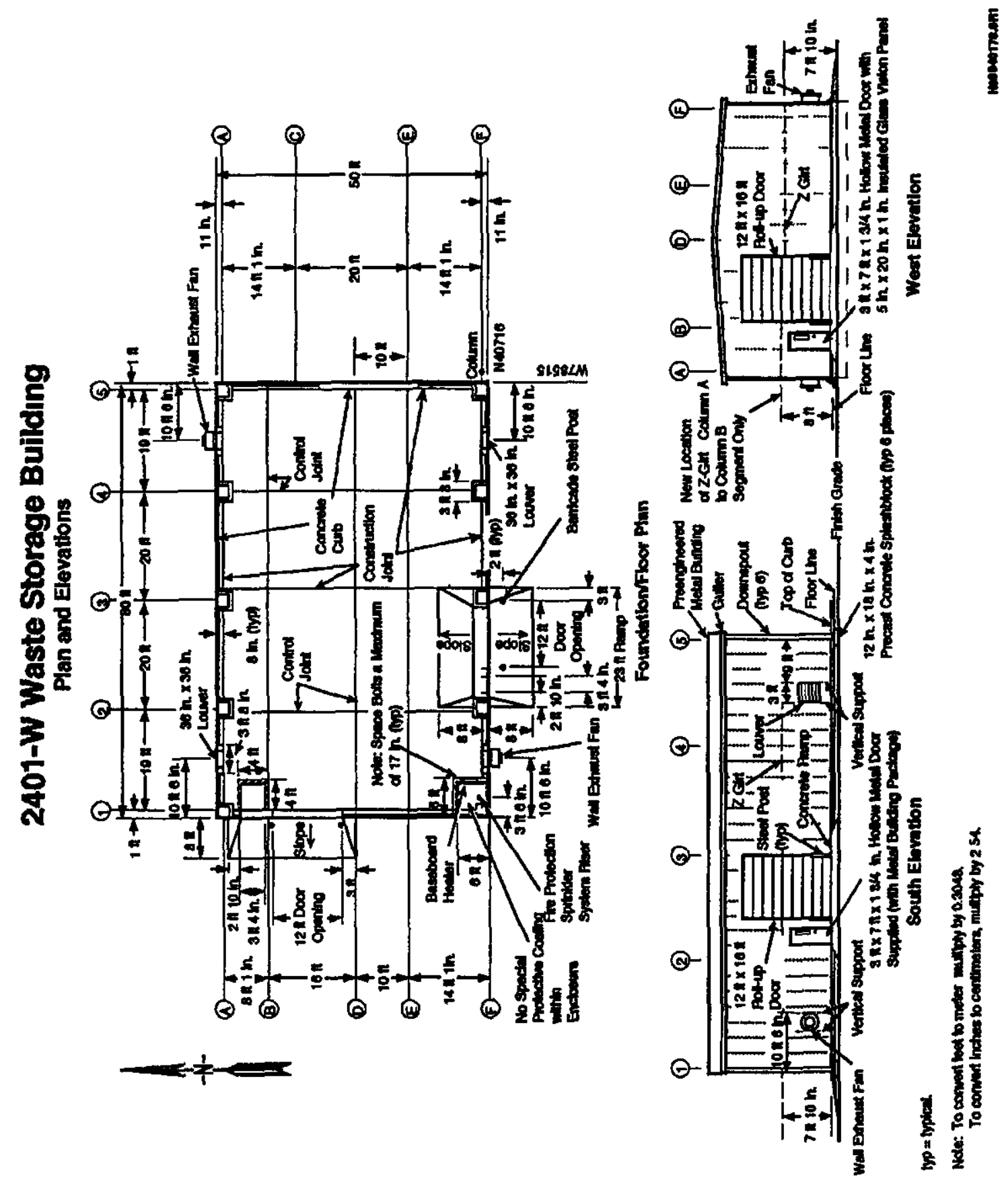

Figure 1-3 2401-W Waste Storage Bulding

F1-3 

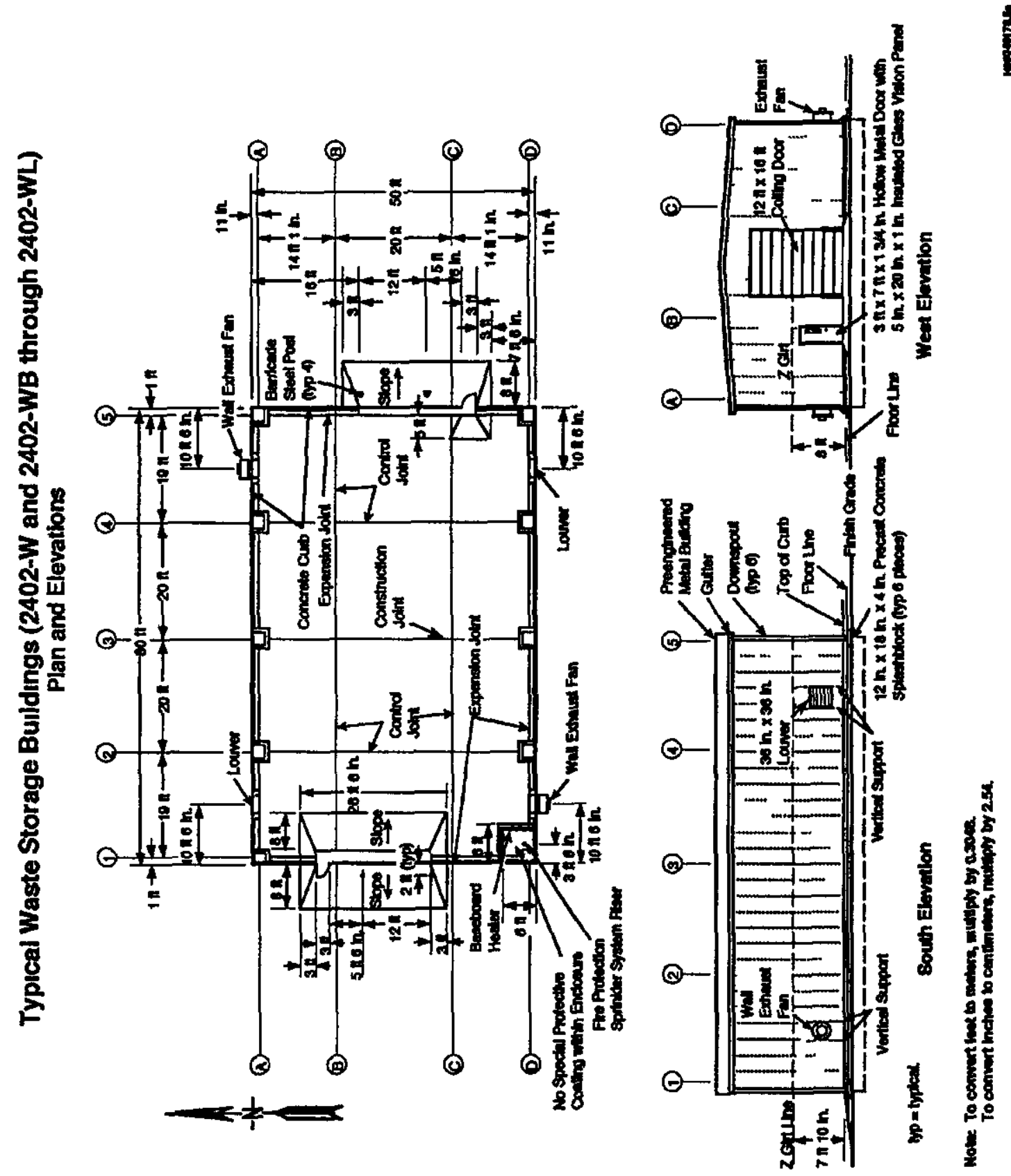

Figure 1-4 2402-W Waste Storage Buılding 

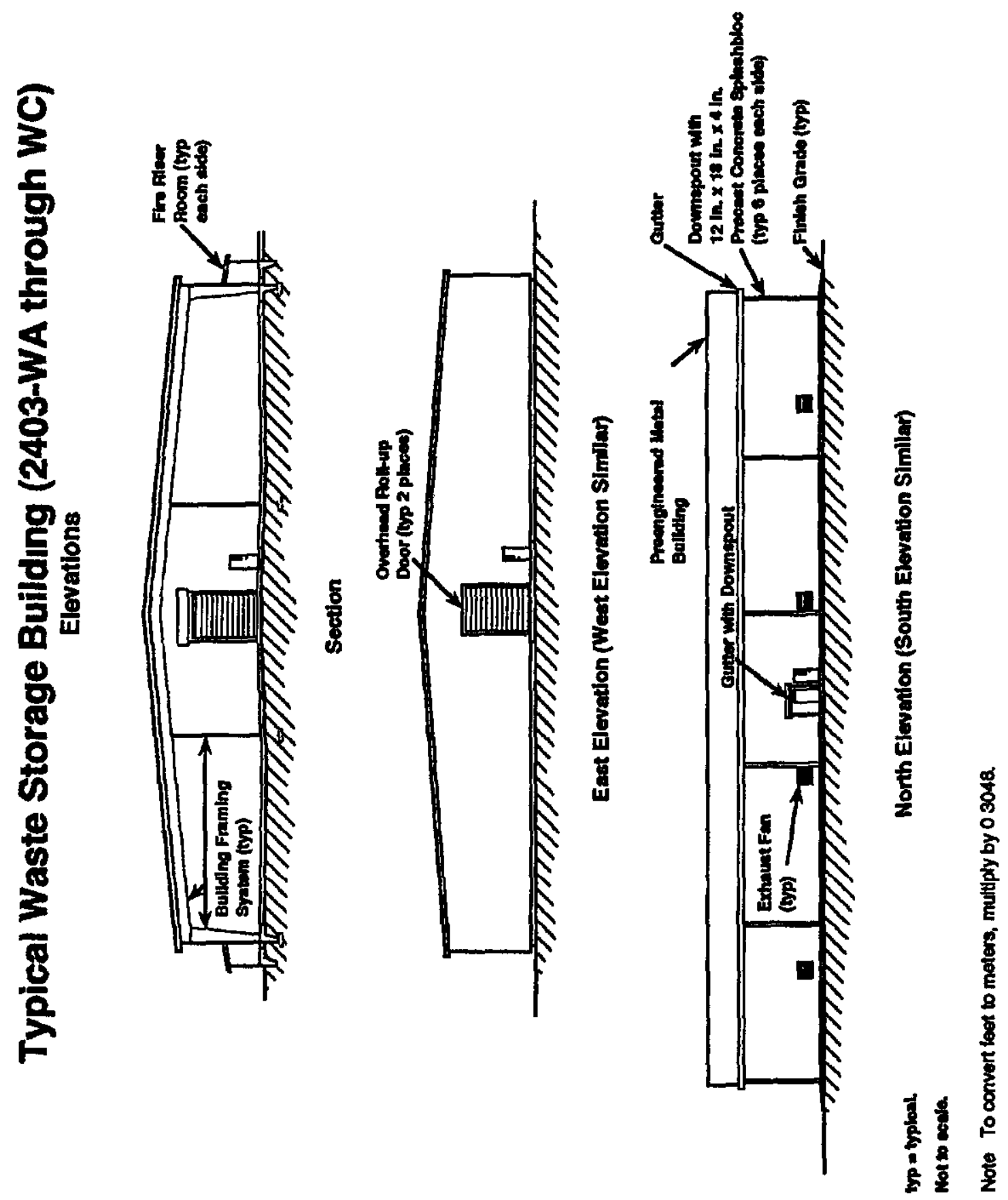

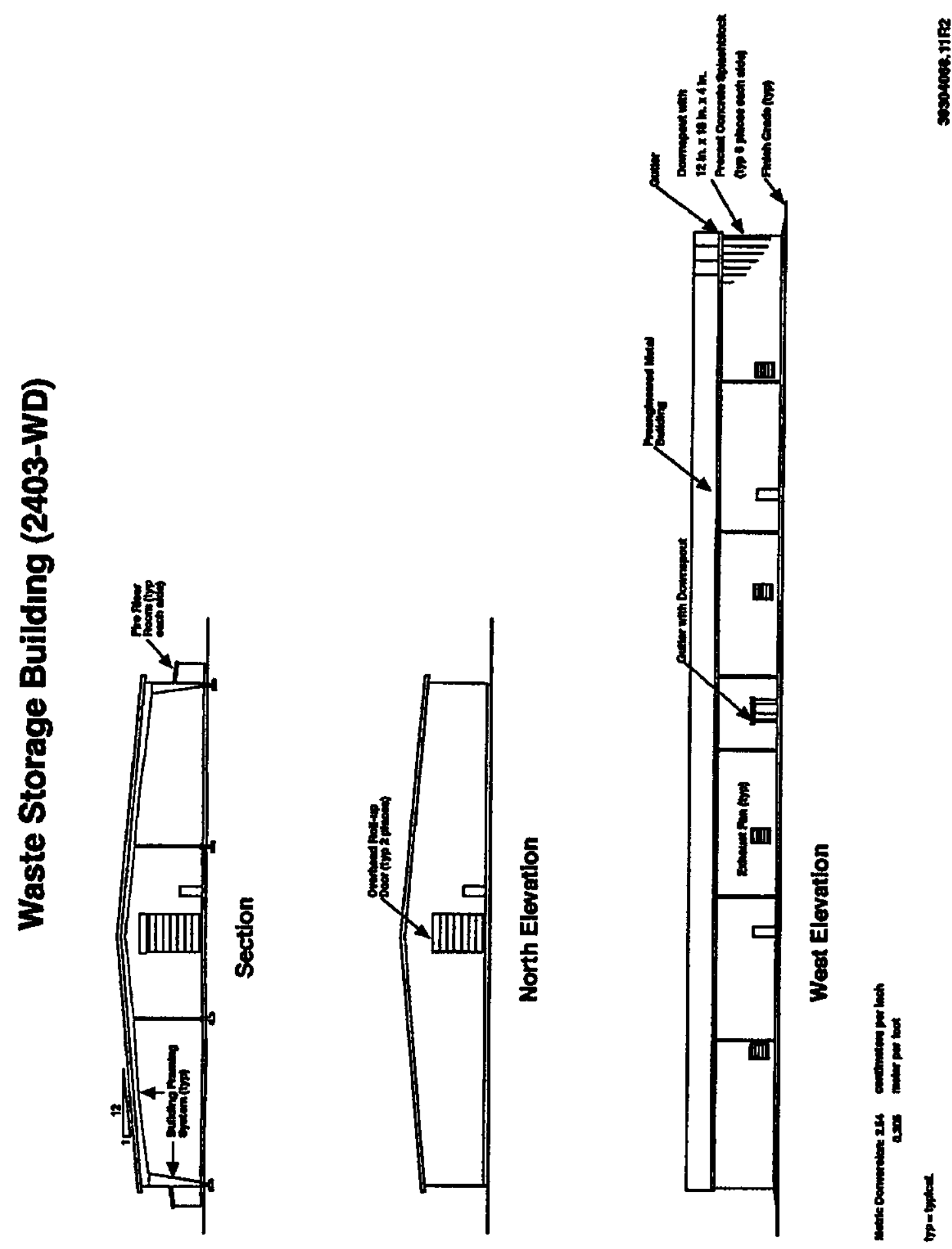

Figure 1-6 2403 WD Waste Storage Building 

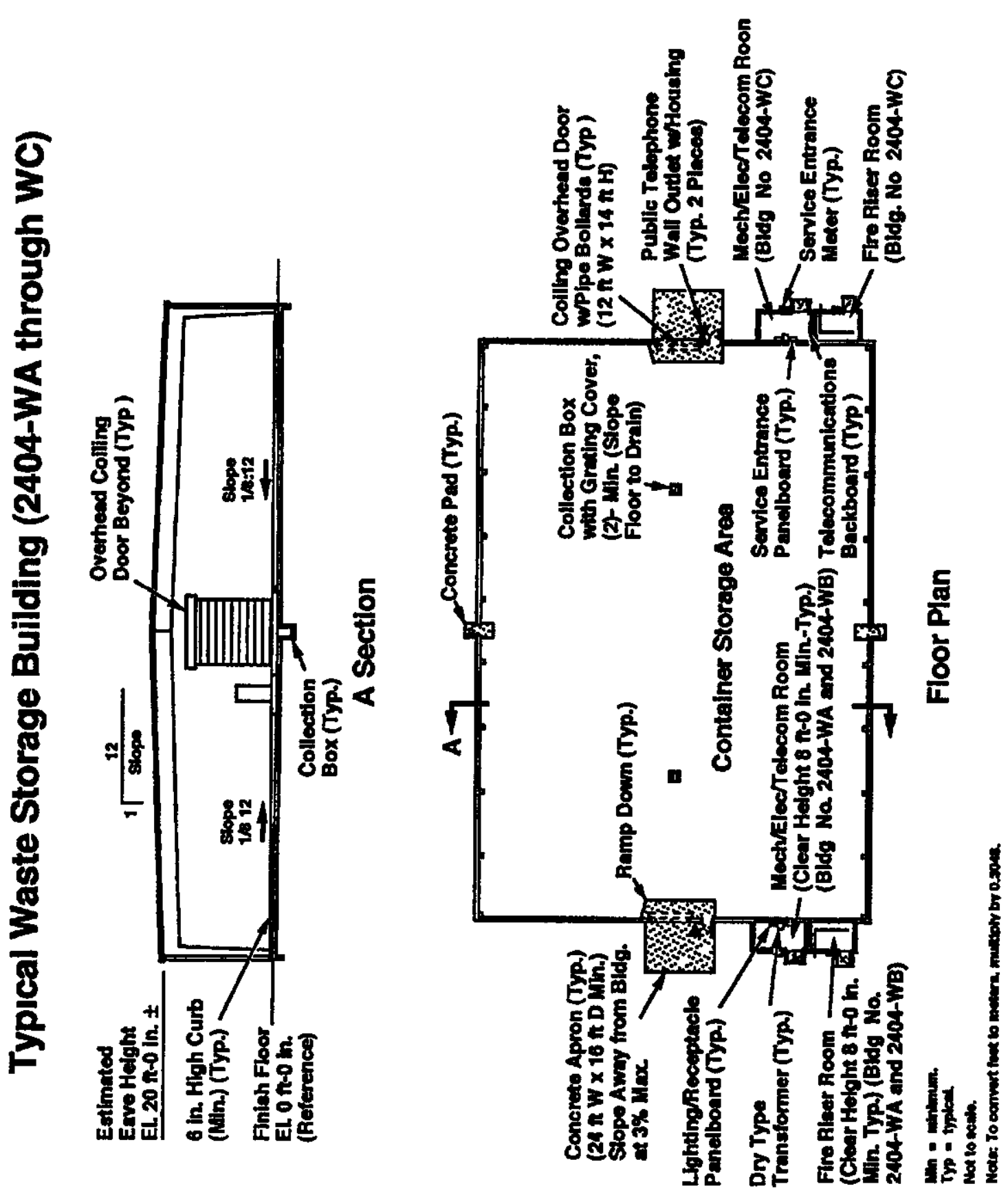

Figure 1-7 2404-W Waste Storage Bulldings 


\section{Waste Storage Pad Civil Plan}

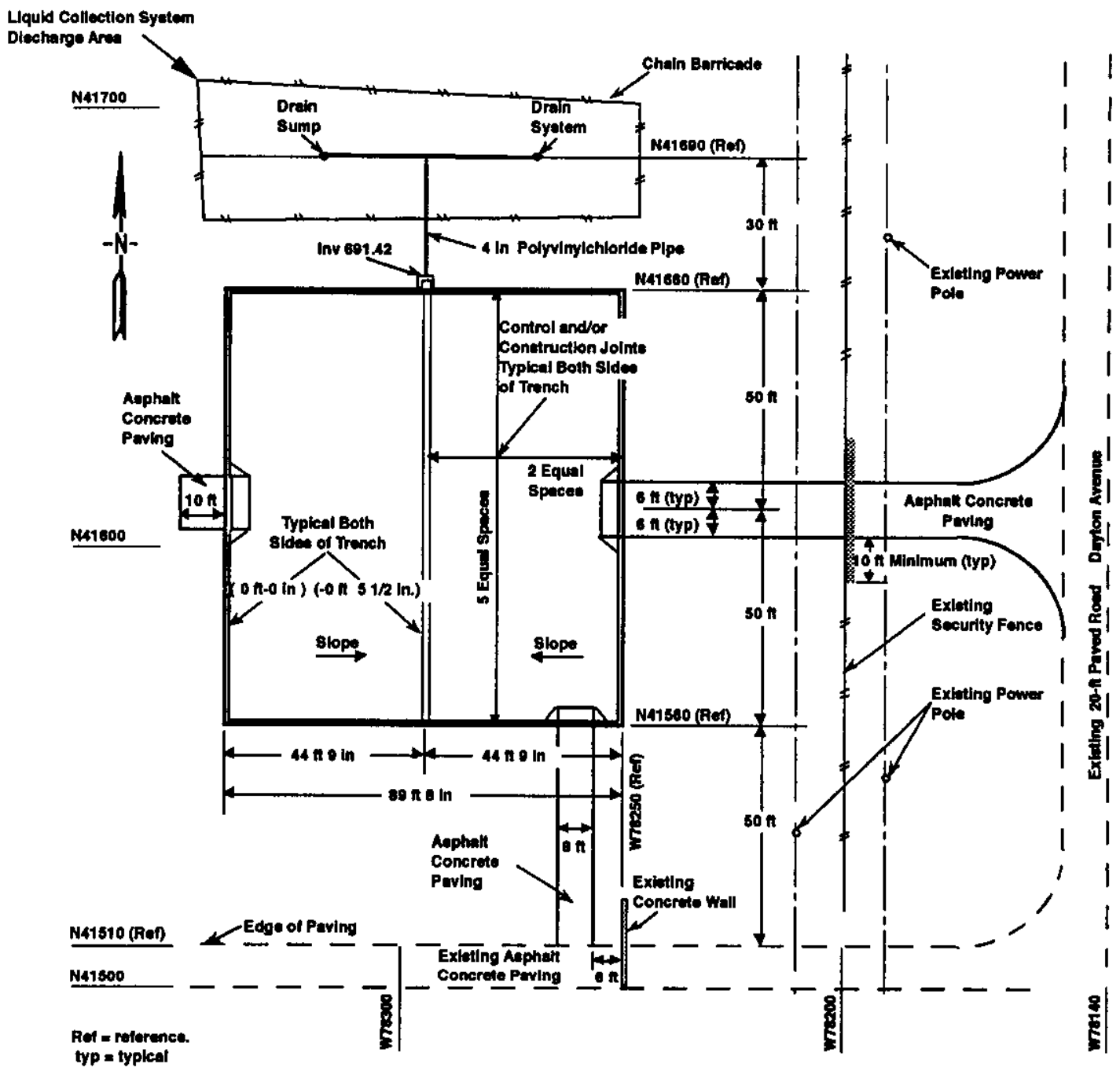

Note. To convert fect to metere, mukiply by 0.3048 To convert inchen to centimeters multiply by $2 \mathrm{bA}$ 
HNF-1886-1

\section{CONFIRMATION PROCESS}

2 The confirmation process includes completıng appropriate pre-shıpment reviews and verification steps

3 | and/or parameters

4

5

\section{PRE-SHIPMENT REVIEW}

Pre-shipment review takes place before waste can be scheduled for transfer or shipment to CWC The review focuses on whether the waste stream is defined accurately, meets the CWC waste acceptance criteria, and the LDR status is determıned correctly Only waste determined to be acceptable for treatment and/or storage is scheduled This determination is based on the information provided by the generator Except for waste transfers among Waste Management Project operated TSD units, the pre shipment review consists of the waste stream approval and waste shipment approval process Previously accepted waste that is transferred from one Waste Management Project operated TSD unit to another does not require the development or approval of a profile The following sections discuss the pre shipment review process The information obtained from the generator during the pre-shipment review at a minımum, includes all information necessary to safely treat and/or store the waste The pre-shıpment review ensures the waste has been characterızed and the data provided qualıfy as 'acceptable knowledge' (Section 213 )

\section{Waste Stream Approval Process}

The waste stream approval process consists of reviewing stream information supplied on a waste stream profile and attached analysis At a minımum, the profile requests the following information

- Generator information (e $\mathrm{g}$, name, address, point of contact, telephone number)

- Waste stream name

- Waste generatıng process description

- Radiological knowledge (e g, classification, reportable radionuclides, characterization method)

- Chemical characterization information (e g, characterization method(s), chemicals present, concentration ranges)

- Designation informatıon

- LDR information including identıfication of underlyıng hazardous constituents if applicable

- Waste type information (e g, physıcal state, sorbents used, inert materıals, stabilizıng agents used)

- Packaging information (e g, container type, maxımum weight, size)

- Attachments could consist of container drawings, process flow information, analytical data, etc 
In some cases such as variable waste streams, the profile information can be general in nature In these cases, more detailed information will be gathered during the waste shipment approval process This information is reviewed against the CWC waste acceptance criteria to ensure the waste is acceptable for receipt If discrepancies are found during this review, additional information is requested that could include analytical data or a sample to be analyzed If the waste cannot be received, the CWC operating organization will pursue acceptance of the waste at an alternative TSD unit or request the generator to pursue acceptance at an offsite facility

On determination that the waste is acceptable, the CWC operatıng organization assigns the profile to a waste management path and establishes a waste verification frequency based on the requirements found in Sections 1113 and 2222

\section{Waste Shupment Approval Process}

For each waste transfer or shipment that is a candidate for treatment and/or storage, the generator provides the following information

- Container identıfication number

- Profile number (except for waste transfers of previously accepted waste)

- Waste description

- Generator information (e g name, address, point-of-contact, telephone number)

- Container information (e g, type, size, weight)

- Waste numbers

- Extremely hazardous waste or dangerous waste

- Dose rate information

- Reportable radionuclides and quantities

- Waste composition

- Packaging materials and quantities

The pertınent information is entered into Solid Waste Information Tracking System (SWITS) Figure 21 is the waste acceptance process

Where potential nonconformances exist in the information provided ( $1 \mathrm{e}$, waste characteristics do not match the waste profile information/CWC waste acceptance criteria, or additional constituents are expected to be present that do not appear on the documentation), the generator is contacted by the CWC operating organization Refer to Section 60 for discussion on repeat and review frequency

For each container, a technical review, physical screenıng determınation, and chemical screening determination are performed as follows

- Technical review Individual container data on waste not previously accepted are compared to the waste profile data to ensure the waste to be transferred/shipped to CWC is as described by the waste profile Every transfer or shipment is reviewed to ensure the waste meets the CWC waste acceptance criterıa

Based on waste identtfication information provided, the waste designation is reviewed to ensure consistency with waste designations per WAC 173-303 070, as well as for technical accuracy to ensure the waste meets the waste acceptance criteria 
If the transfer or shipment information is found to be acceptable, the CWC operating organization determines if any of the waste containers will be physically or chemically screened

- Physical screening determination Containers are chosen based on the methodology described in this section The first criterion is based on whether pre-shipment review activities (document and characterization review) identify areas of potential concern The second criterion is reviewing the current physical screening percentage to ensure that the minımum physical screening confirmation rates and stream criteria required by this WAP are met

- The number of containers initially selected for physical screening constitutes a sample set

- Individual containers withın a transfer or shipment are selected based on a review of the contents listed in the associated documentation

- Containers are selected at random unless variability within the stream is noted In this case containers representıng different variations are selected $(\mathrm{e} g$, wood debris versus metallic debris)

\section{Acceptable Knowledge Requirements}

The CWC operating organization ensures that all information used to make waste management decisions are based adequate characterization data, as described in the following sections The CWC operating organization evaluates the data to ensure that the data are adequate acceptable knowledge for management of the waste

\section{General Acceptable Knowledge Requirements}

Adequate acceptable knowledge includes (1) general waste knowledge requirements, (2) LDR waste knowledge requirements and/or (3) waste knowledge exceptions

(1) General Waste Knowledge Requirements At a mınımum, the generator supplies enough information for the waste to be treated and/or stored at CWC The minimum level of acceptable knowledge consists of designation data where the constituents causing a waste number to be assigned are quantified, and the data address any CWC operational parameters necessary for proper management of the waste

Where the avallable information does not qualify as acceptable knowledge or is not sufficient to characterize a waste for management, the sampling and testing methods outlined in WAC 173-303 110 must be used to determine whether a waste designates as toxic characteristic, corrosive, and/or contains free liquids

If a generator's process knowledge indicates that constituents, which if present in the waste might 
cause the waste to be regulated are input to a process but not expected to be in the waste sampling and analysis must be performed to ensure the constituents are not present above regulatory limits in the waste This requirement can be met through chemical screening as long as the constituents of concern can be measured by the screening method This sampling and analysis is required only for initial characterization of the waste stream

(2) LDR Waste Knowledge Waste might be stored in CWC while awaitıng analytical results for LDR requirements The CWC operatıng record contains all information required to document that the appropriate treatment standards have been met or will be met after the waste is treated unless otherwise excepted in this section

For the purposes of this WAP a representative sample is required to demonstrate complance with a concentration based treatment standard (refer to Section 4 5) Corroborative testing for the sample could be accomplished in the following manner

- Generators could use onsite laboratories or other laboratories to certify that the waste meets LDR requirements For waste that does not meet LDR requirements, the generator must supply information on the treatment methods necessary to meet LDR requirements and in accordance with WAC 173-303 380(1)(o)

- The CWC operatıng organization uses these analytical data to ensure that the applicable requirements found in 40 CFR 2687 and WAC 173-303 140(4) are met

(3) Waste Knowledge Exceptions In some situations, full characterization of waste for cradle to grave management is not possible or feasible before receipt at CWC for storage For storage purposes, waste analysis requirements could be met through application of partial acceptable knowledge when such knowledge provides sufficient information to ensure that waste will be stored properly Acceptable knowledge could be used to accommodate storage at CWC for the following

- Waste previously disposed before the effective date of the regulation that has been or will be retrieved for storage at $\mathrm{CWC}$, and for which adequate information has been obtained to ensure proper storage at CWC

- Waste placed in storage before the effective date of this waste analysis plan for which adequate information has been obtained to ensure proper storage at CWC

- Newly-generated waste for which adequate information has been obtained to ensure proper storage at CWC

For situations in which acceptable knowledge has been used to accommodate storage, such information will be supplemented as necessary before treatment and/or disposal of the waste

\section{Methodology to Ensure Compliance with Land Disposal Restrictions Requirements}

All generators are subject to LDR requirements and are required to submit all information notifications and certifications described in WAC 173 303-380(1)(n) or (o) Mixed waste not meeting the treatment standards, but meetıng the CWC waste acceptance criteria, can be stored at CWC (refer to Chapter 10 , Section $1 \quad 1 \quad 11$ ) The following are general requirements for offsite notifications or onsite information and supportıng documentation 
- The waste is subject to LDR and the generator has treated the waste The generator supplies the appropriate LDR certification information (40 CFR 268)

- The waste is subject to LDR and the generator has determined that the waste meets the LDR as generated The generator develops the certification based on process knowledge, and/or analytical data and supplies the appropriate LDR certification information necessary to demonstrate compliance with the LDR treatment standards of 40 CFR 268 and WAC 173303140 State-only LDRs do not require this type of certification

- The waste is subject to LDR and requires further treatment to meet applicable treatment standard The generator supplies additional information concerning the waste and details any treatment necessary to meet applicable treatment standards

When demonstrating that a concentration-based treatment standard has been met, a representative sample of the waste must be submitted for analysis This sample could be taken by the CWC operating organization or the generator, and is required to comply with the treatment standards contained in 40 CFR 26840 and 26848

\section{VERIFICATION}

Verification is an evaluation performed by the CWC operatıng organization to substantiate that the waste received at $\mathrm{CWC}$ is the same as represented by the analysis supplied by the generator for the pre-shipment review Verification is performed on waste received by CWC Verification includes container receipt inspection, physical screening, and chemical screening Waste is not accepted by CWC for treatment and/or storage untıl required elements of verification have been completed, including evaluation of any data obtained from verification activities

All discrepancies identified during the verification process are resolved in accordance with Section 11133

\section{Container Receipt Inspection}

33 The container receipt inspection is a mandatory element of the confirmation process Therefore, 100 percent of the transfers/shipments are inspected for damage and to ensure the waste containers are those indicated on the documentation This activity is a mechanism for identifying any document discrepancies or damaged containers before acceptance The container receipt inspection is performed by the CWC operatıng organization at CWC or at another onsite location The CWC operatıng organization ensures that the transfer/shipment (1) is received in good condition, (2) is the waste indicated on the manifest or shipping papers, (3) has not been opened improperly after physical and/or chemical screening was performed and (4) is complete

\section{Physical Screening Process}

44 Physical screening is considered an additional verification element This section describes the requirement pertaining to methods, frequency, and exceptions concerning the use of physical screening as a verification activity Physical screening could be performed before the waste is transferred/shipped to CWC When screening is performed at a location not within the Waste Management Project (e $g$, 
WRAP T Plant Complex, Low-Level Burial Grounds), unique tamper resistant seals are applied to each container examined Selection, interpretation, and performance of the appropriate physical screening method(s) are conducted by qualified personnel

\section{Physical Screening Methods}

Each of the following physical screening methods, listed in order of preference, complies with the requirement to verify a waste If a method other than 1 or 2 is used, the reasoning behind the method chosen must be documented in the operating record (refer to Section 31 for the criteria for choosing a physical screening method)

1 Visual inspection (opening the container)

2 NDE

3 Nondestructıve assay (NDA)

4 Dose rate profile

Refer to Section 225 for quality control pertaining to physical screenıng

\section{Physical Screening Frequency}

The mınımum physıcal screenıng frequency is 5 percent for onsite generators applied per waste stream ${ }^{2}$ per subcontractor per year For offsite generators, the minımum physical screening frequency is 10 percent per waste stream per generator per year The CWC operating organization adjusts the physical screenıng frequency for generators based on objectıve performance criteria (refer to Section 111131 )

In the event that one of the containers in the original sample set fails, a second sample set of equal size, | or a minimum of three additional containers, is selected First and second sample sets are selected using the rationale described in the pre-shipment review section (Section 21 ) A second failure in either the first or the second sample set constitutes fallure of the transfer/shipment If the second sample set passes the inspection the single failed container is considered an anomaly and the remainder of the transfer/shipment passes verification All falled containers and transfer/shipments are dispositioned via the PES as described in Section 1113

When physical screenıng is performed at a location not withın the Waste Management Project, tamper resistant seals are applied to each outer container examıned

\section{Physical Screening Exceptions}

37 The following exceptions to the physical screening process outlined previously have been developed

- Shielded, classified, transuranic (TRU) retrieved waste and remote-handled mixed waste are not required to be physically screened, however, the CWC operatıng organization must perform a more rigorous documentation review and obtain the raw data used to characterize the waste $(<1$ percent of current waste receipts) For classified waste, it is necessary to have an appropriate U S Department

2 The term waste stream as referred to in the context of phystcal screening frequencies refers to general waste grouping for treatment/disposal and should not be equated to the waste stream referred to in the waste profile discussion 
of Energy security clearance and a need to know the information as defined by the classifying organization or agency

- Waste that physically cannot be screened at CWC or associated screening facility must be physically screened at the generator location (e $g$ large components, containers that cannot be opened are greater than 20 mrem per hour, contain greater than 10 nanocuries per gram of TRU radionuclides, or will not fit into the NDE unit) If no location can be found to perform the physical screening no screening is required

- Waste that is packaged by the CWC operating organization is considered to have met the physical screening requirements noted in this WAP (e g, CWC operatıng organization packaged waste that is transferred to a Waste Management Project managed unit) On closure of the container, tamper resistant seals must be applied to ensure the integrity of the contents

\section{Chemical Screening Process}

Chemical screening is considered an additional verification element This section describes methods, frequency, and exceptions for chemical screening Chemical screening could be performed by the CWC operating organization before waste is transferred/shipped to CWC After chemical screening is performed, tamper resistant seals are applied on each outer container screened The requirements described for tamper resistant seals used for physical screenıng apply for chemical screenıng as well

Selection, and interpretation, and performance of the appropriate chemical screening method(s) are conducted by qualified personnel Unless otherwise noted, tests are qualitative not quantitative The objective of chemical screening is to obtain reasonable assurance that the waste received is consistent with the description of the waste on the waste profile, and to provide information that will be used to safely manage the waste The following tests are selected depending on the waste matrix and the applicability of the method A minimum of three listed screening tests, including pH screening are conducted on each sample If less than five of the following methods are selected, the rationale is recorded by the qualified analyst

The following tests are conducted on all samples collected for chemical screening

- $\mathrm{pH}$

- Peroxide

- Oxidizer

- Water reactivity

Additionally the following screening tests could be performed as needed

- Halogenated organic carbon (chlor n o1l/water/soil)

- Ignitability/headspace screening for volatile compounds

- Sulfide

- Cyanide

- Paint filter liquids test

Refer to Section 2252 for quality control pertaining to chemical screenıng 


\section{Chemical Screenıng Frequency}

2 At a mınımum 10 percent of the mixed waste containers verıfied by physical screenıng (Section 2222 )

3 must be screened chemically Although grab samples are acceptable, the CWC operatıng organızation

4 obtains a representative sample

Small containers of waste (labpacks), not otherwise identified in the exceptions, packaged in accordance with 40 CFR 265316 and WAC 173303161 are screened chemically in accordance with the waste stream chemical screenıng frequency as determıned by PES (Section 11113 ) Inner containers are segregated by physical appearance At least one container from each group (or three containers if all are similar) are screened chemically

\section{Chemical Screening Exceptions}

The following are cases in which chemical screening is not required

- Small containers of waste in overpacked containers (labpacks) packaged in accordance with WAC 173303161 and not prohıbited under LDR specified in WAC 173-303140

- Waste exempted from the physical screening requirements (Section 2223 ) is exempted from chemical screenıng

- Commercial chemical products in the original product container(s) (e g, off-specification, outdated or unused products)

- Chemıcal contaınıng equipment removed from service, (e g, ballasts, batteries)

- Waste containıng asbestos

- Waste, environmental media, and/or debris from the cleanup of spills or release of single substance or commercial product or otherwise known material (e $\mathrm{g}$, material for which an MSDS can be provided)

- Confirmed nonınfectious waste (e g, xylene, acetone, ethyl alcohol, isopropyl alcohol) generated from laboratory tissue preparatıon, slide staining, or fixing processes

- Hazardous debris as defined in WAC 173 303-040

Other special cases could be exempted from chemical screening on a case-by-case basis

\section{Sampling for Confirmation Screening}

41 Sampling is performed in accordance with WAC 173-303-110(2) A representative sample is obtained 42 for chemical screening The chemical screening methods described in Section 30 do not require any 43 sample preservation methods because the screening tests are performed at the time and location of 44 sampling or as soon as possible thereafter During the interim period, the samples are stored in a 45 manner that maintains chain of custody and protects the sample composition 
1 The equipment requirements in Section 4 0, Table 4-1, apply to sampling for chemical screening In addition, the following sampling equipment could be used in sampling for chemical screening (1) for liquids and slurries - dip, tank, bomb, and baller samplers, as well as tube-type samplers (e $\mathrm{g}$, thınwalled Shelby tubes, split spoons, probes, pipettes), and for sludges and solids - tube-type samplers (as previously mentioned) and augers, and for small containers, a spoon could be used in place of a scoop

\section{Quality Assurance and Quality Control for Confirmation Process}

The following quality assurance (QA) and quality control (QC) elements are used by the CWC operatıng organization to ensure confirmation activities provide sufficient data to provide an indication that waste received is as described in the transfer/shipment documentation

\section{Physical Screening Quality Control}

This section describes the $\mathrm{QC}$ used by the $\mathrm{CWC}$ operating organization or its representative to ensure that quality data are obtaıned when performing physical screenıng methods identıfied in Section 22 2, except visual inspection Visual inspection does not consist of the use of instrumentation or chemical tests Therefore QC for visual inspection depends on appropriate training for the individual(s) performing the test For the remaining physical screening tools (NDE, NDA, and dose rate profile), QC for these methods is incorporated in accordance with manufacturer $s$ instructions or site specific protocols If any results are questionable, those affected containers must be re evaluated and handled appropriately

\section{Chemical Screening Quality Control}

This section describes the $\mathrm{QC}$ used by the CWC operating organization or its representative to ensure that appropriate data are obtained when performing chemical screening methods identified in Section 223

The following applies for all chemical screening parameters

- Each lot will be evaluated to determıne that the lot is useable Unstable reagents will be accounted for when determining the usability of the lot

- For each lot, the source concentration, date of receipt, lot number, and manufacturer/preparer (as applicable) will be maintained in a logbook

- For individual chemical screenıng parameters, QC checks will be performed in accordance with manufacturer's instructions or site specific protocols 


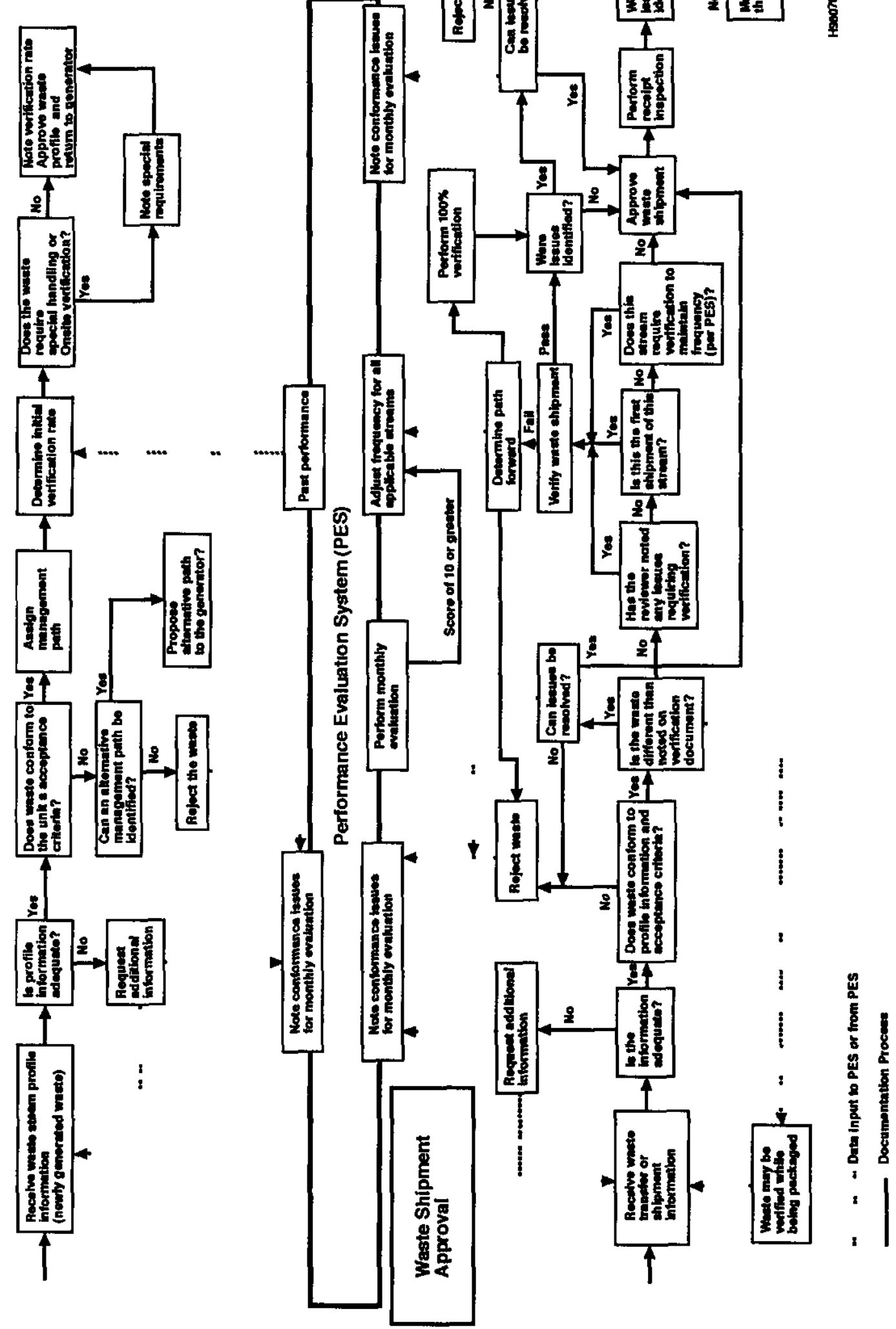

Figure 21 Waste Acceptance Process 
HNF-1886 1

Physical and chemical screening parameters for verification must be chosen from those in Section 31 and 32 Other samplıng and analysis parameters are addressed in Section 33

\section{PHYSICAL SCREENING PARAMETERS}

6 | The following methods are approved for use in performing physical screening These methods are listed in order of preference If a method other than 1 or 2 is used, the reasoning behind the method selection will be documented

\section{(1) Visual inspection (preferred method for physical screenıng)}

Rationale This method meets the requirement to ensure consistency between waste containers and the accompanying transfer/shipment documentation

Method The container is opened and the contents are removed as needed for visual examination Homogenous loose solids are probed to determine the presence of material not documented or for improperly sorbed liquids Visual observations are compared with the applicable profile information and the container specific information in the transfer/shipment documentation

(2) $\mathrm{NDE}$

Falure criteria A container fails the inspection for any of the following reasons (a) undocumented or improperly packaged waste, (b) discovery of prohibited artıcles or materials listed in Section 12 (c) discovery of material not consistent with the applicable waste stream profile, and (d) variability greater than 25 percent by volume in listed constituents (e g paper plastıc, cloth, metal)

Rationale This method meets the requirement to ensure consistency between waste containers and the accompanying transfer/shipment documentation This method also is subject to the QA checks listed in Section 2251 Containers that are not easily amenable to visual inspection because of physical or radiological content, or facility avalability, can be safely and economically examined

Method The container is scanned with a NDE system Data are observed on a video monitor and captured on video tape Personnel experienced with the interpretation of NDE imagery record their observations These observations are compared to the contents listed on the transfer/shipment documentation

Fallure criteria A container fails the inspection for any of the following reasons (a) undocumented, improperly packaged, or inadequately sorbed liquids, (b) discovery of prohibited articles listed in Section 1 2, (c) image data not consistent with the applicable waste stream profile, and (d) variability greater than 25 percent by volume in listed constituents (e $\mathrm{g}$, paper, plastic, cloth, metal) 

(3) NDA
Rationale This method is available for obtaining data that can be compared with accompanying transfer/shipment documentation for consistency on containers that cannot be opened for visual inspection, and cannot be examined by NDE (e g, high container dose rate, shielding) The reason for selection of this method is documented
Method Radioactive waste is assayed in one or both of two different assay systems The assay systems include gamma energy analysis (GEA) and imaging passive/actıve neutron (IPAN) Gamma emittıng radionuclides are detected in the GEA assay system This instrument determines the type and quantity of radionuclides based on their gamma energy spectrum IPAN uses passive and active neutron detection to determine the presence of fissionable radionuchides Passive detection results are equated with $\mathrm{Pu} 240$ and active detection results are equated with $\mathrm{Pu} 239$ The curie amount of low energy gamma emitting radionuclides, other fissile and non-fissile alpha emitting radionuclides, and beta emitting radionuclides are calculated from the GEA and IPAN data and the generator supplied radionuclide information Radionuclide ratios are calculated by dividing the activity of each radionuclide reported by the activity of the most prominent radionuclide

Fallure criteria A container fails the assay if the difference between the reported radionuclide ratios and the measured ratios and the reported and measured curie amounts exceed 50 percent The fallure criteria are adjusted based on the density of the waste and the amount of fissionable matersal present

(4) Dose rate profile

Rationale This method is used to obtain data that can be compared for consistency with the transfer/shipment documentation for a container This method is used only when the previous three methods cannot be performed for technological or ALARA reasons (e $g$, container size, weight, shielding, dose rate) The reason for selection of this method is documented

Method A portable dose rate meter is used to determine the contact dose rate at six evenly distributed points on the exterior of the waste package The six readings obtained are recorded and averaged The average reading is compared with the container contact dose rate recorded on the transfer/shipment documentation

Failure criterna If the average dose rate observed during the dose rate profile examination differs from that recorded on the transfer/shipment documentation by more than 100 percent, the container fails

\section{CHEMICAL SCREENING PARAMETERS}

The following methods are approved for use in performing chemical screening

Ignitability and/or headspace volatıle organic compound screening

Rationale To determine the potential ignitability and the presence or absence of volatile organic compounds in waste, and to ensure personnel adequately are protected This method is used when containers are opened for inspection This method can be applied to any matrix 
Method A sample of the headspace gases in a container is analyzed by one or more of the following types of portable instrumentation organic vapor monitor, colorimetric gas sampling tubes, or a lower explosive level meter

Tolerance High organic vapor readings in matrices not documented as having volatile organic content constitutes failure

(2) Peroxide screening

Rationale To determine the presence of organic peroxides in solvent wastes, to alert personnel to potential hazards, to ensure safe segregation and storage of incompatible wastes, and to confirm consistency with the transfer/shipment documentation The test is sensitive to low parts per million ranges

Method A peroxide test strip is dampened with a pipette sample of liquid waste Solids are tested by first wetting the test strip with water and contacting a small sample of the waste A blue color change indicates a positive reaction The color change can be compared with a chart on the packaging to determine an approximate organic peroxide concentration

Tolerance Peroxide concentrations greater than 20 parts per million in liquid waste constituents that are known organic peroxide formers not documented as having been stabilized constitutes fallure

(3) Paint filter liquids test

Rationale To verify the presence or absence of free hquid in solid or semisolid material

Method To a standard paint filter 100 cubic centımeters or 100 grams of waste are added and allowed to settle for 5 minutes Any liquid passing through the filter signifies fallure of the test

Tolerance Fallure of the test in waste matrices not documented as having free liquids constitutes fallure of the container Small quantities of condensate trapped in inner plastic liner folds are acceptable

(4) pH screen

Rationale To identify the $\mathrm{pH}$ and corrosive nature of an aqueous or solid waste, to ensure safe segregation and storage of incompatıble waste, and to confirm consistency with the transfer/shtpment documentation

Method Full range pH paper is used for the initial screening If the initial screen indicates a $\mathrm{pH}$ below 4 or above 10 , a pH meter could be used, or a narrow range $\mathrm{pH}$ paper Solids are mixed with an equal weight of water and the liquid portion of the solution is tested

Tolerance $\mathrm{pH}$ paper for this test has a sensitivity of $+/-10 \mathrm{pH}$ units If the $\mathrm{pH}$ of a matrix appears to exceed regulatory limits $(<20$ or $>125)$ in waste not documented as being regulated for this property the container fails the test 
(5) Oxıd1zer screen

Rationale To determine if a waste exhibits oxıdizing properties to ensure safe segregation and storage of incompatible waste, and to confirm consistency with the transfer/shipment documentation This test can be applied to waste liquids solids, and semisolids

Method Acidified potassium iodide (KI) test paper is applied to solid or liquid waste A darkening of the paper is a positive indication

Tolerance This method is very sensitive to oxidizing properties A positive indication in a waste that cannot be explained by documented constituents constitutes fallure

(6) Water reactivity screen

Rationale To determine if the waste has the potential to vigorously react with water, form gases or other reaction products This information is used to ensure safe segregation and storage of incompatıble waste, and to confirm consistency with the transfer/shipment documentation

Method Water is added to a sample of solid or liquid waste The solution is observed for evidence or fuming, bubbling spattering, or temperature change These reactions are considered to be positive evidence that the waste is water reactive

Tolerance A positive indication in a waste that cannot be explained by documented constituents constitutes a fallure

\section{(7) Cyanide screen}

Rationale To indicate if waste could release hydrogen cyanide upon acidification near $\mathrm{pH} 2$ This information is used to ensure safe segregation and storage of incompatible waste, and to confirm consistency with the transfer/shipment documentation

Method To a test tube or watch dish containing approximately 2 milligrams of sample, an equal amount of freshly prepared ferrous ammonium citrate is added 3 Normal hydrochloric acid is used to reduce the $\mathrm{pH}$ of the solution to near 20 A deep blue color indicates the presence of cyanide

Tolerance A positive indication in a waste that cannot be explained by documented constituents constitutes a fallure

\section{(8) Sulfide screen}

Rationale To indicate if the waste could release hydrogen sulfide upon acidification near $\mathrm{pH} 2$ This information is used to ensure safe segregation and storage of incompatible wastes, and to confirm consistency with the transfer/shipment documentation

Method Approximately 2 milligrams of sample is added to a watch dish or test tube and enough 3 Normal hydrochloric acid is added to bring the $\mathrm{pH}$ down to near 20 A sulfide test strip is placed in the solution If the paper turns brown or silvery black, the presence of sulfides in the sample is indicated 
1 Tolerance A positive indication in a waste that cannot be explained by documented constituents

(9) HOC screen

\section{OTHER ANALYSIS PARAMETERS}

22 Parameters needed to meet other waste characterization needs for waste stored at CWC are identified in 23 Appendix A 
HNF-1886-1

1

2

3

4

5

This page intentionally left blank 


\section{SELECTING SAMPLING PROCEDURES}

Specific sampling procedures and techniques depend on both the nature of the material and the type of packaging This section describes the sampling methodology used to obtain representative samples

\section{SAMPLING STRATEGIES}

Table 41 contains waste forms and sample equipment used to sample referenced waste Sampling of these waste forms is performed in accordance with Table 4-1

\section{SAMPLING METHODS}

The appropriate personnel are responsible for arranging all sampling and laboratory support for sample analysis Samples are processed at one of several laboratories qualıfied to perform analysis of waste samples (refer to Section 50 ) Sampling methods are those described in WAC 173303 110(2)

The basic sampling sequence is as follows

- Obtain a unique sample number and complete the sample tag before sampling

- Obtain a precleaned sampler and sample bottles

- Attach sample label to sample bottles

- For sampling liquid waste a sampler or pipette will be used to sample for two phase liquids Homogeneous liquids in small containers will be poured into a sample bottle

- For sampling solid waste a scoop trier, or hand auger will be used to obtain a sample of the waste For large containers of waste composite several augers or scoops to ensure samples are representatıve

- Fill sample containers in the following sequence volatıle organics, semivolatıle organics, metals ignitability $\mathrm{pH}$ (corrosivity)

- For solid waste, wipe the exterior surfaces of the sample bottles with a dry rag

- Attach sample labels to outer plastic bags

- Place samples in an appropriate receptacle for transfer to the laboratory

- Complete the chain of-custody forms

- Seal and mark the receptacle in accordance with WAC 173-303 071(3)(1)

- Transfer receptacle to the analytical laboratory as appropriate to meet sample holding times 
- Properly clean and decontaminate nondisposable samplıng equipment or package for return to central sampling equipment decontamination area according to onsite requirements

\section{SELECTING SAMPLING EQUIPMENT}

\section{ESTABLISHING QUALITY ASSURANCE AND QUALITY CONTROL PROCEDURES FOR SAMPLING}

The sampling team ensures all samples are labeled with a unique identıfier

Sample collectors prepare a permanent log of sampling activities Log entries include as appropriate date of collection, time of collection, location, batch number sample number, copy of the chain of-custody form, sampling methodology, container description, waste matrix (liquid), description of generating process ( $\mathrm{g}$, decontamination activities), number and volume of samples, field observations, field measurements (e $\mathrm{g}, \mathrm{pH}$, percent lower explosive lımit), laboratory destınation and laboratory number and signature These logs entries are made by the appropriate personnel ${ }^{3}$ while the sampling is performed The logs are permanent records of the TSD unit and must be retained in the Operating Record If sampling is conducted in a posted radiological zone, the logbook entries could be made by a person who is outside the zone or by the sampler immediately after the sampling is completed The sampling logs are retained in accordance with standard industrial practices A chain of custody record accompanies samples at all times The record contains a unique sample number for each sample date and time of collection, sample type, sample location, methods of transfer and signatures (or electronic equivalent, e $g$ signature password) of the collector and all subsequent custodians

Durıng all samplıng actıvitıes, strıct compliance with applicable industrial hygiene and safety standards is mandatory If sampling personnel accidentally contact waste material, decontamination of sampling personnel is performed immediately Transportation of samples is performed in accordance with all applicable onsite and U S Department of Transportation requirements

The following QA/QC elements are used by the CWC operatıng organization to ensure sampling actıvities for designation purposes result in acceptable laboratory data

- Representative sampling methods as defined by WAC 173 303-110(2), 40 CFR 261 Appendix I, and/or SW-846 Chapter 9

- Appropriate sample containers and equipment

| 'appropriate personnel' are defined as sampling personnel or a person directed by a sampler 


\section{HNF 1886-1}

2

3

4

5

6

7

8

9 - Chain of custody 


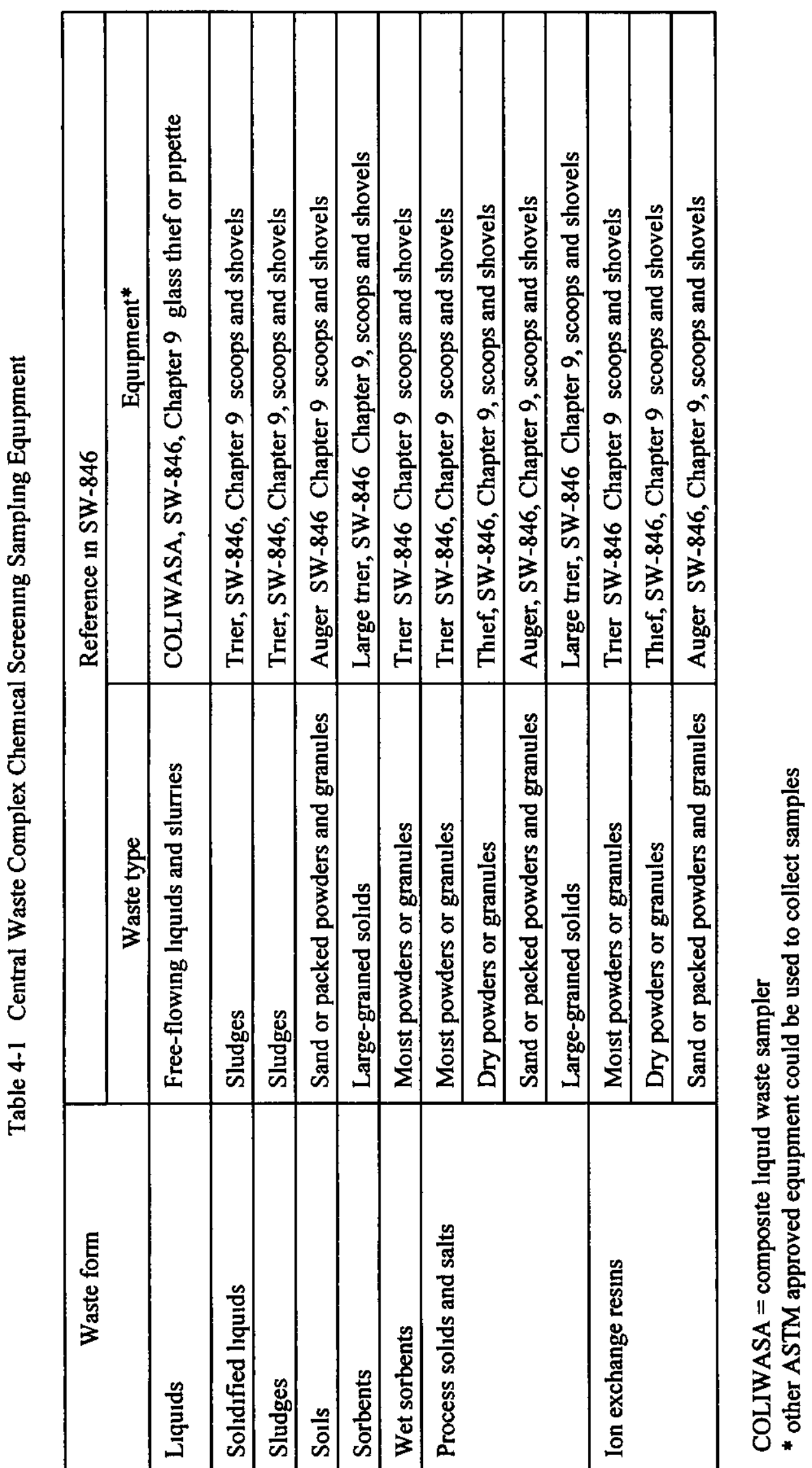




\section{HNF 1886-1}

\section{1}

2

3

4

5

This page intentionally left blank 


\section{SAMPLING AND ANALYTICAL PROGRAM}

QC will be applied in implementıng both sampling and analytical techniques Specific performance standards for QA and QC methods for individual sampling and analysis activities are dynamic and are revised as warranted to reflect technological advances in available, appropriate techniques These performance standards are described in policies maintained at $\mathrm{CWC}$ and are avalable for review on request

These sampling and analytical quality policies help ensure that the sample obtained provides precise and accurate analytical results for the waste being sampled The analytical results are used by CWC operating organization to decide whether or not to accept a partıcular waste On acceptance, results are used to determine the appropriate method of treatment and storage and that incompatible waste is not combined inadvertently Just as these analytical results are important, so is the quality of the sampling program

\section{SAMPLING PROGRAM}

Sampling procedures for CWC operations are described in Section 224 Selection of sample collection devices depends on the type of sample the sample container, the sampling location, and the nature and distribution of regulated constituents in the waste In general, the methodologies used correspond to those referenced by 40 CFR Part 261, Appendix I The selection and use of the sample collection device are supervised or performed by qualıfied personnel

Sampling equipment are constructed of materials that nonreactive with the waste being sampled Materials such as glass, polyvinyl chloride plastic, alumınum, or stainless steel could be used Care is taken in the selection and use of the sample collection device to prevent contamination of the sample and to ensure compatibility with the waste being sampled Individual container samples that are related and compatıble could be composited before analysis

\section{ANALYTICAL PROGRAM}

A program of analytical QC practices and methods has been developed on the Hanford Site to ensure that precision and accuracy are maintained throughout the laboratories Good laboratory practices that encompass sampling sample handling housekeeping and safety are maintained at onsite laboratories 


\section{HNF-1886 1}

This page intentionally left blank 


\section{SELECTING WASTE RE-EVALUATION FREQUENCIES}

2 The re evaluation (repeat and review) frequency to review profile information is yearly, or more often if 3 the waste generation process changes

4

5 | Thee CWC operating organization re-evaluates a waste profile if the following occurs

6

7 - A generator notıfies the CWC operatıng organization that the generatıng process has changed

- Inspection or analysis indicates that the waste received at CWC does not match the profile and/or

| transfer/shipment documentation

When a waste profile is re-evaluated the CWC operating organızation could request the generator to do one of the following

- Verify the current waste profile is accurate

- Supply a new waste profile

- Submit a sample for parameter analysis 


\section{HNF 1886-1}

This page intentionally left blank 
HNF-1886-1

\section{SPECIAL PROCEDURAL REQUIREMENTS}

This section discusses any special process requirements for receiving mixed waste at CWC

\section{PROCEDURES FOR RECEIVING WASTE GENERATED ONSITE}

In general, mixed waste received from onsite generator units is managed the same as waste received from offsite generators Differences include, but are not limited, to the following (1) physical and chemical screening frequencies for verification (minımum percentages of 5 percent for waste from onsite generatıng units and 10 percent for waste from offsite generators (note that chemical screenıng frequency depends on the physical screenıng frequency) (2) transfer/shipment documentation (Uniform Hazardous Waste Manifest are used for waste from offsite generators and waste tracking forms are used for waste from onsite generatıng units), and (3) LDR documentation requirements (notıfication for waste from offsite generators and the information contained in the notice for waste from onsite generating units)

\section{PROCEDURES FOR RECEIVING WASTE GENERATED OFFSITE}

Waste received from offsite is handled in the same manner as mixed waste received from onsite except as denoted in Section 71

\section{PROCEDURES FOR IGNITABLE, REACTIVE, AND INCOMPATIBLE WASTE}

CWC accepts ignitable, reactive, or incompatible waste (refer to Section 12 ) The following precautions are taken before ignitable, reactive, or incompatible waste is accepted at CWC

- Pre shipment review and/or chemical screening identify whether the waste is ignitable, reactive or incompatıble

- CWC waste acceptance criteria identıfies storage requirements for ignitable, reactıve, and incompatible waste ensuring the waste is stored in a safe manner

The types of prohibited waste are identıfied in Section 12

\section{PROVISIONS FOR COMPLYING WITH FEDERAL AND STATE LAND DISPOSAL RESTRICTION REQUIREMENTS}

Although CWC does not treat LDR waste, sampling could be performed at CWC to support LDR certification The following sections are required for treatment of LDR waste

Federal and state-only LDR requirements restrict the land disposal of certain types of waste subject to Resource Conservation and Recovery Act (RCRA) of 1976 and the Washington State Hazardous Waste Management Act of 1976 Waste managed on the Hanford Site falls within the purview of these LDRs per 40 CFR 268 and WAC 173 303-140 Waste constituents that are subject to LDRs are identified in 40 CFR 26840 and referenced by WAC 173-303 140 Waste must meet certain treatment standards as specified in 40 CFR 26840 and WAC 173-303 140, if the waste is to be land disposed 
1 Generators (as defined in the regulation) determine if LDRs apply to the waste based on knowledge or testing [40 CFR 268 7(a)] Each waste is analyzed for those LDR constituents contained in the listed and characteristic waste numbers identıfied by the generator, if the generator's knowledge is not sufficient to make a determination If the LDR waste does not meet the applicable treatment standards the generator (Section 1111 ) provides information statıng so with each transfer/shipment of waste, in accordance with WAC 173-303-380(1)(j) (k),-(n) or -(o) If the waste meets the standards the generator must send a certification that the waste meets the treatment standards

\section{Waste Treatment}

Retrieved and newly generated waste is treated to meet LDR as specified in 40 CFR 26840 and WAC 173 303-140 with the exception of TRU mixed waste TRU mixed waste is treated to the applicable standards required by the Waste Isolation Pilot Plant or other generator requirements An onsite TSD unit potentially can pretreat certain waste before shipment to a permitted offsite facility that could perform full treatment of the specific waste to meet full LDR Waste requiring treatment other than what an onsite TSD unit can provide is repackaged labeled and transferred to a TSD unit for storage pending identification or development of an appropriate treatment

LDR requirements apply to all mixed waste except a small class of state-only waste When evaluating the treatability of certain characteristic waste, consideration must be given to any additional underlying hazardous constituents that might be found in the waste The treatment standards, for the most part, are concentration-based If the constituent concentrations for the waste fall below those specified in 40 CFR 26840 and/or 26848 for underlying hazardous constituents and in WAC 173 303-140, the waste can be land disposed without being treated If the concentrations exceed these limits, the waste must be treated before disposal

Specific treatments performed onsite include but are not limited to, deactivation, encapsulation stabilization, and amalgamation

Deactıvation is used to remove the hazardous characteristıcs of the waste due to its ignitability (D001) corrosivity (D002) solid corrosive acid (WSC2), and/or reactivity (D003) Treatment techniques include but are not limited to neutralization, cementing, absorption, controlled reaction with water, and macroencapsulation

- Neutralization is the primary method of treatment for corrosive waste that has a $\mathrm{pH} \leq 2$ and/or $\geq 125$ Examples of bases that could be used as neutralizing agents include sodium hydroxide, calcium hydroxide, or calcium carbonate Examples of acids that could be used to neutralıze bases are hydrochloric acid and sulfuric acid

- Absorption is the primary method of treatment for ignitable waste which includes waste that is hquid and has a low total organic carbon content ( $<10$ percent) Absorbent material that could be used includes polyacrylates, polypropylene, polymer type superabsorbent polymer, cellulose, or other absorbent materials meetıng various disposal requirements

- Cementıng or groutıng is the primary method of treatment for ignitables consisting of metal fines or | other corrosive materials These types of waste are deactivated by mixing and binding the waste with an inert cementacious material 
- Controlled reaction with water is the primary method of treatment for reactive materials such as sodium metal This process will deactivate the material and allow for further disposition

- Macroencapsulation with polyethylene plastic containers is the primary treatment for debris For elemental lead, macroencapsulation is performed in accordance with Table 1 of 40 CFR 26842

Stabilization methods used include cementing or groutıng, sealıng, and sorption Partıculates and/or liquid waste containing hazardous constituents could be cemented or grouted to meet either RCRA LDR, Waste Isolation Pilot Plant waste acceptance criteria, and/or the disposal criteria of future TSD units The waste is stabılized by mixing and binding the waste with an inert material The inert material generally used is Portland cement When dealing with some waste streams such as sludges that might contain an inconsistent or excess liquid content sorbent could be added to the waste to provide a drier matrix to allow identification of the proper combination of ingredients to ensure a successful stabilization effort

Amalgamation of liquid elemental mercury (D009) is achieved using inorganic reagents such as copper, zinc, nickel, gold and sulfur The resultant matrix is a nonliquid solid or semı solid visually inspected to verify compliance

Treatment of state-only extremely hazardous waste (WT01, WP01, and WP03) is performed in accordance with RCW 70105 050(2) and/or WAC 173303 140(4)(a) as applicable

\section{Sampling and Analytical Methods}

If waste is sampled and analyzed to demonstrate that a federal LDR has been met, only U S Environmental Protection Agency methods are used Waste is analyzed using the methods outlined in 40 CFR 26840 and WAC 173303 140(4)(b) or any other relıable method allowed by regulations

Samples of waste are transferred to the sample management area for packaging and transferred to an onsite laboratory or shipped offsite to a laboratory for analysis Samples are collected and analyzed in accordance with SW-846 or any other method allowed by regulations Storage is provided for waste contaners while waiting for laboratory analysis results

\section{Land Disposal Restriction Certification of Treatment}

When LDR treatment has been completed and analytical results (if applicable per 40 CFR 26840 and WAC 173-303-140) have verified that the LDR treatment is successful, certification of the LDR treatment is required The certification statement is prepared by the onsite TSD unit in accordance with 40 CFR 2687 A copy of the certification is placed in the operating record

When a LDR waste does not meet the applicable treatment standards set forth in 40 CFR 26840 and WAC 173-303-140, or exceeds the application prohibition levels set forth in 40 CFR 26832 or Section 3004(d) of RCRA, this information is placed in the CWC operating record in accordance with WAC 173 303-380(1)(k), (n),-(o) 


\section{HNF 1886-1}

1

2

3

4

5

This page intentionally left blank 
HNF-1886-1

\section{RECORDKEEPING}

2 Recordkeeping requirements that are applicable to this WAP are described in Chapter 12 0, Table 12-1, 3 Hanford Facility Dangerous Waste Permit Application General Information Portion (DOE/RL-91 28) 4 and within this WAP 


\section{HNF-1886 1}

1

2

3

4

5

This page intentionally left blank 


\section{REFERENCES}

DOE/RL-88-21, Hanford Facllity Dangerous Waste Part A Permit Application, U S Department of Energy, Richland Operations Office, Richland, Washıngton

DOE/RL-91-28, Hanford Factlity Dangerous Waste Permit Application General Information Portion U S Department of Energy, Richland Operations Office, Richland, Washıngton, revised periodically

EPA SW 846, Test Methods for Evaluating Solid Waste Physical/Chemical Methods Third Edition, as amended, U S Environmental Protection Agency, Washıngton, D C

EPA 600/4 7-020, Methods for Chemical Analysis of Water and Wastes, U S Environmental Protection Agency, Environmental Monitoring and Support Laboratory Cincinnatı Ohıo

62 FR 62079, Mved Waste Testıng Gutdance, November 20, 1997 


\section{HNF-1886-1}

1

2

3

4

5

This page intentionally left blank 
HNF-1886 1

1

2

3

4

5

ANALYTICAL PARAMETERS, METHODS, AND RATIONALE FOR WASTE RECEIVED AT CENTRAL WASTE COMPLEX 


\section{HNF-1886 1}

This page intentionally left blank 
HNF-1886-1

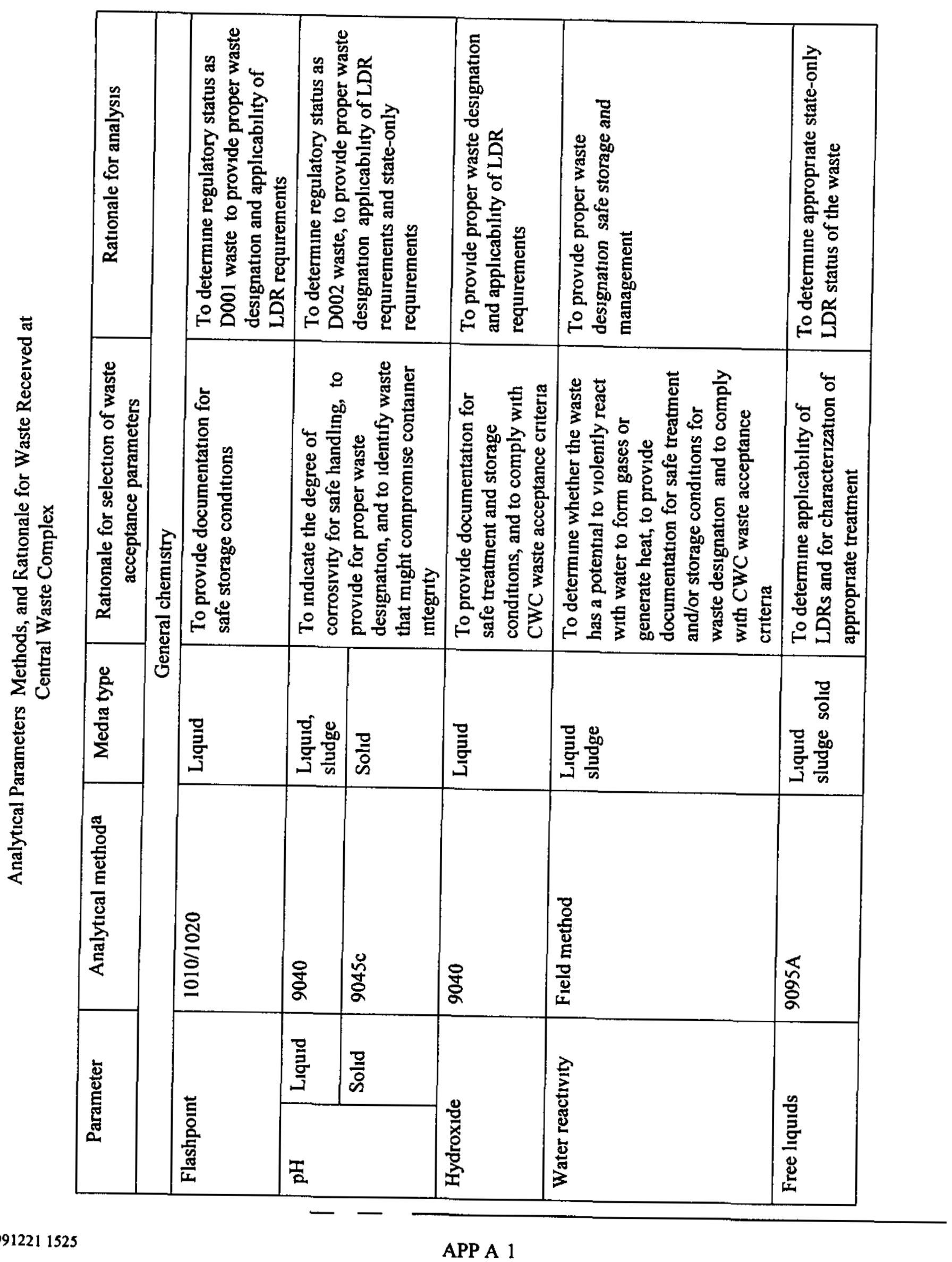


HNF-1886-1

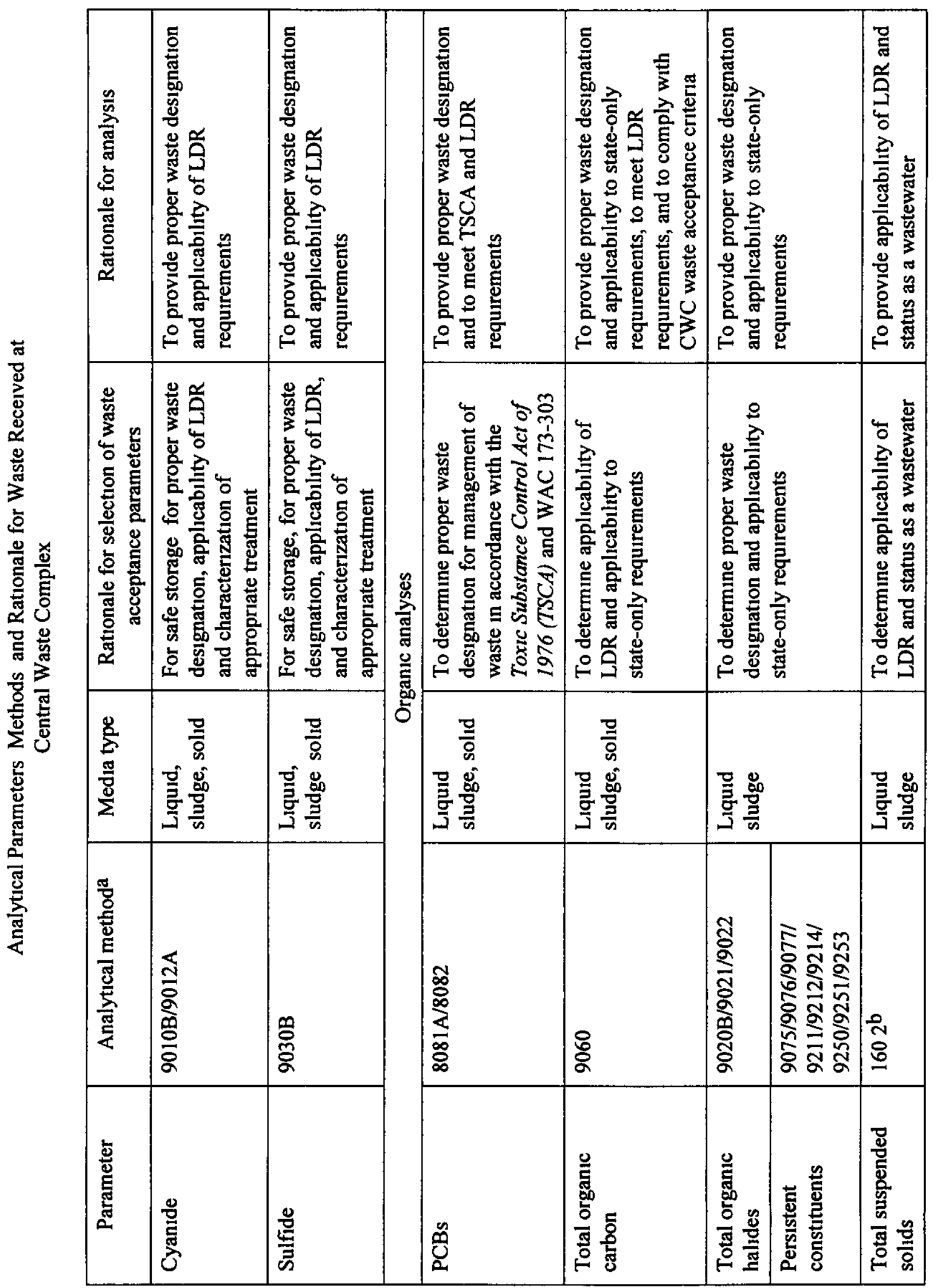


HNF-1886-1

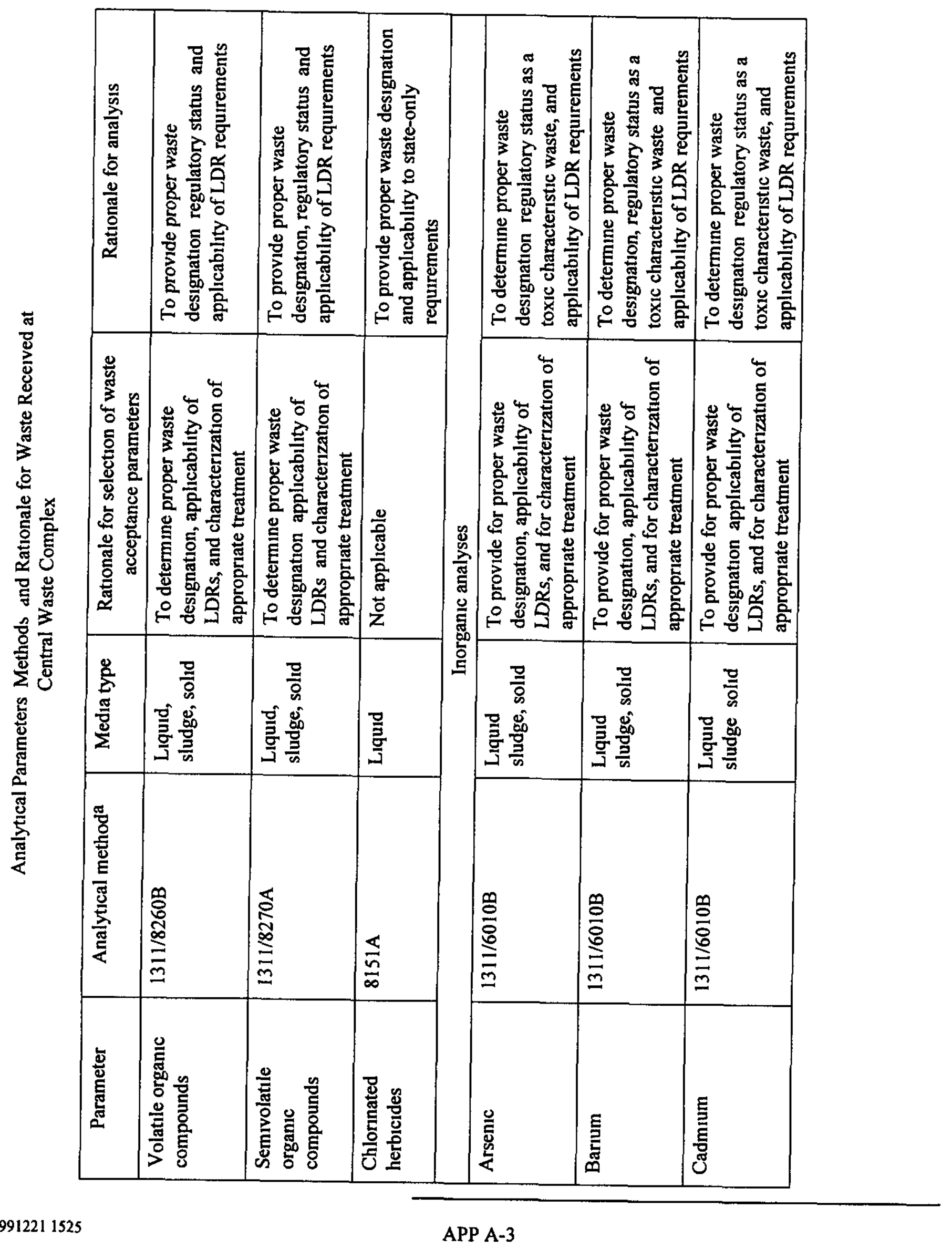




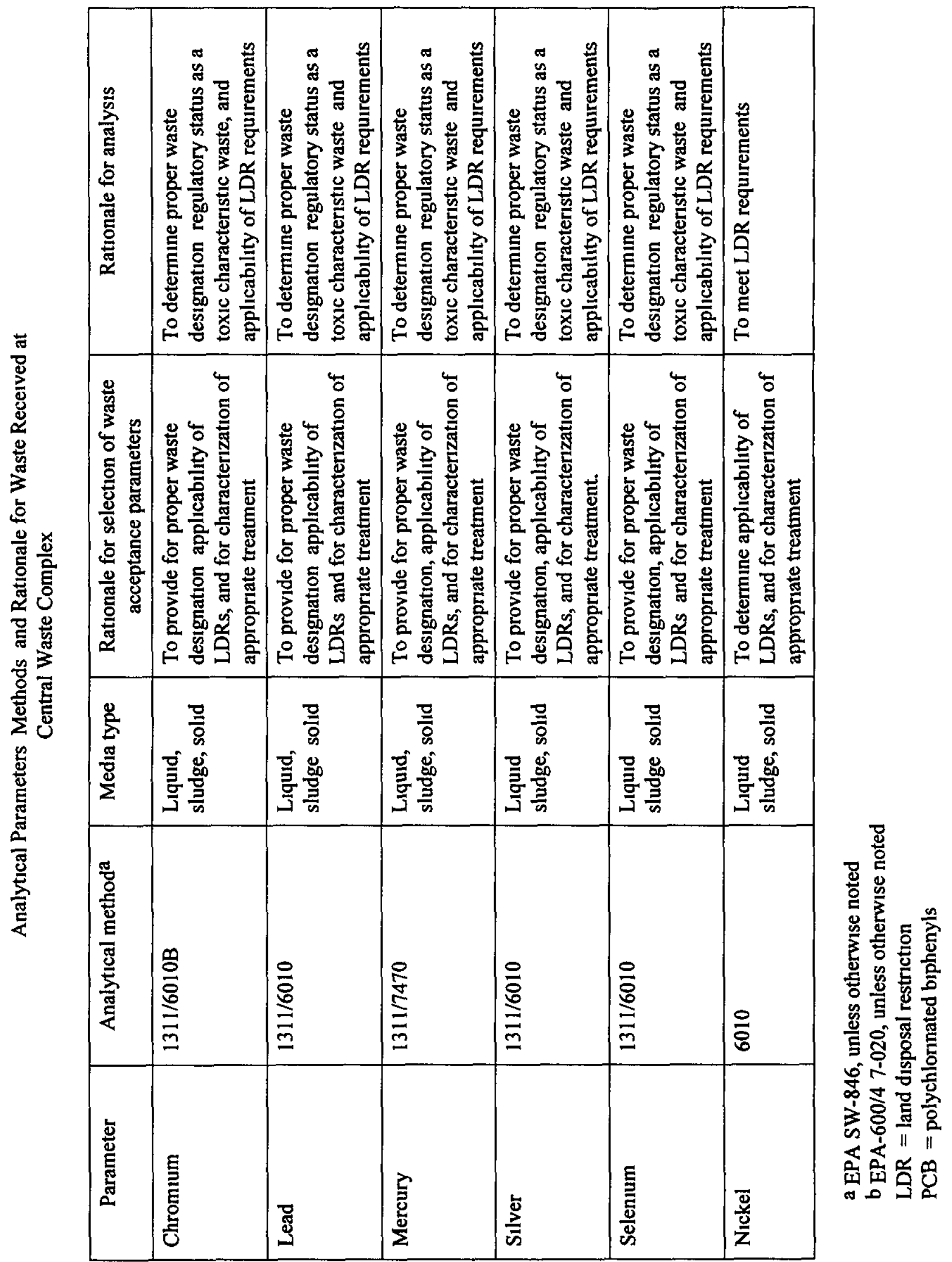


HNF-1886-1

\section{DISTRIBUTION}

MSIN

Fluor Daniel Hanford, Inc

J B Buckley Jr

T4-05

C K Girres

T3-01

J O Hanley

T4 05

F D Sargent

T4 03

D G Saueressig

T4-04

G C Triner

T3 05

J F Williams Jr

G1 30

Lockheed Martın Services, Inc

Central Files

B1 07

DPC

H6 08 
HNF-1886-1

This page intentionally left blank 